\title{
العلاقة بين المسؤولية الاجتماعية وتنافسية اقتصاديات دول العالم الإسلامي
}

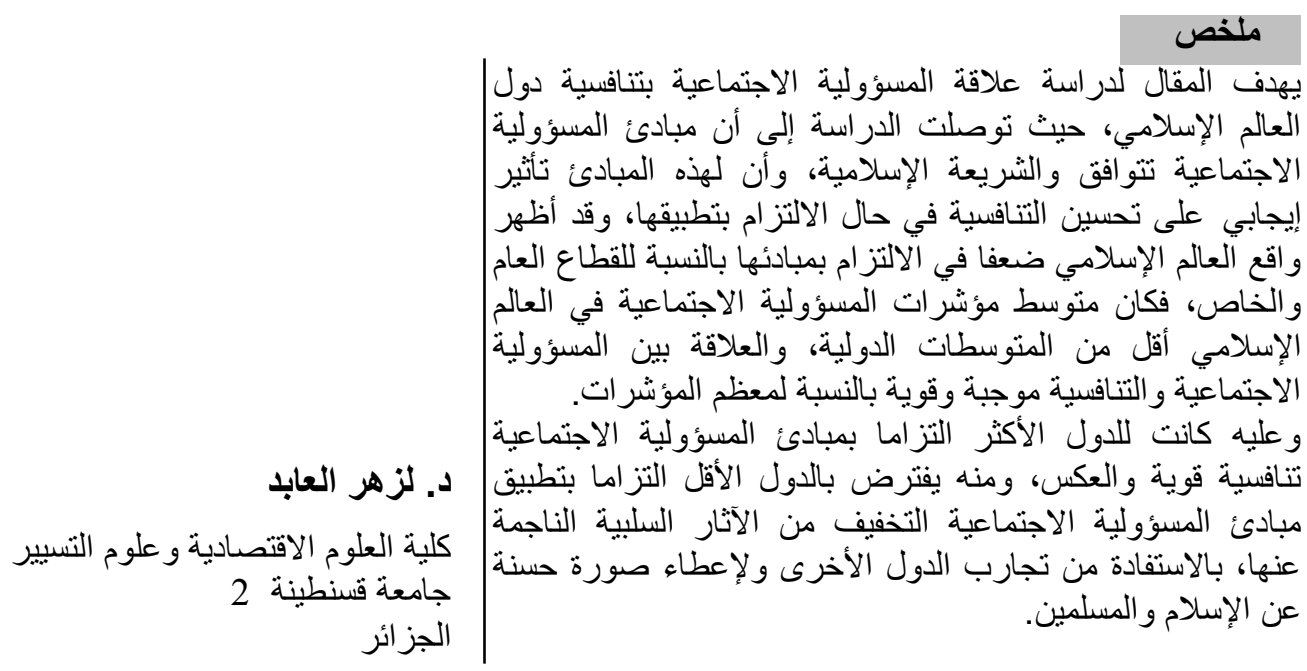

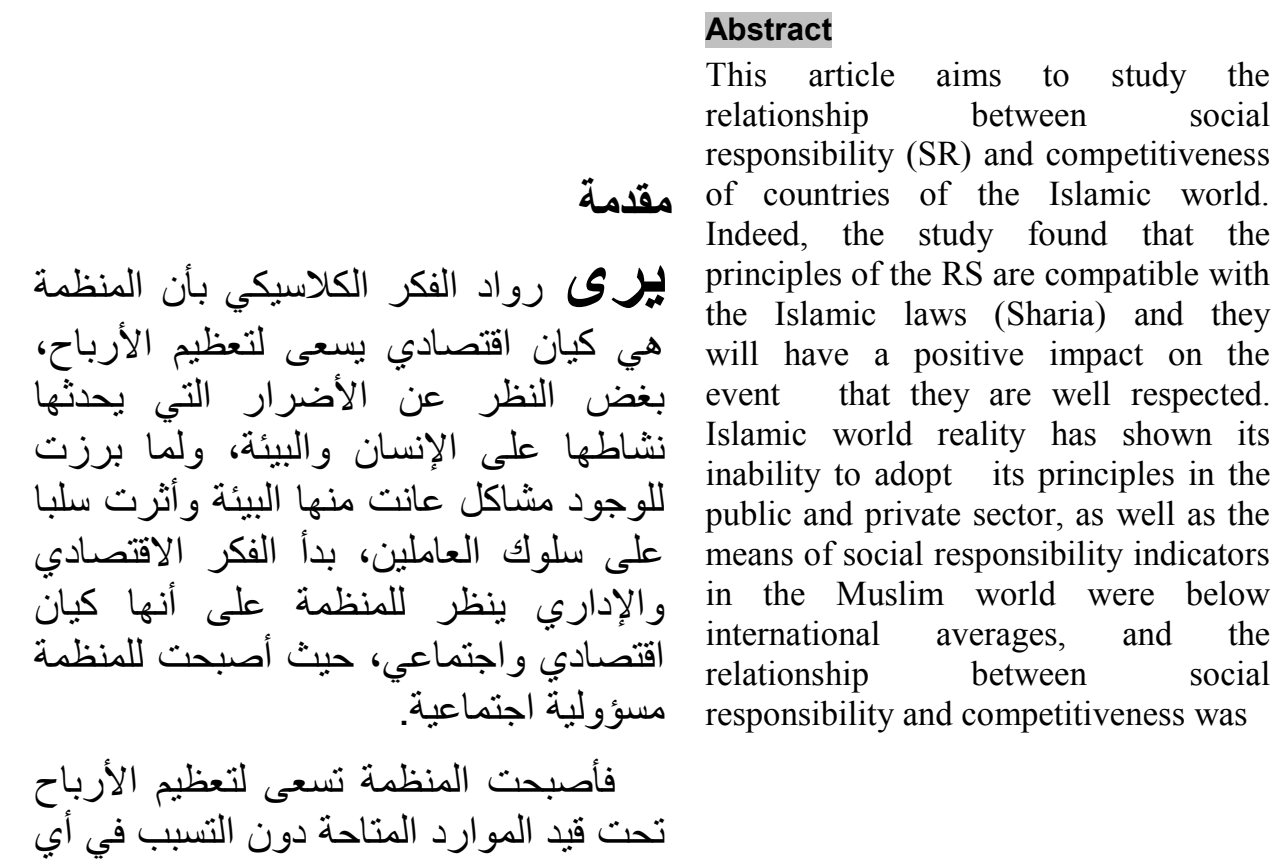

(؟ جامعة قسنطينة 1، الجزائر 2015 
ضرر لأصحاب المصلحة، ويمثل هذا الحد الحئ الأدنى لتطبيق المسؤولية الاجتماعية، وهو

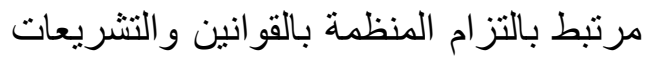

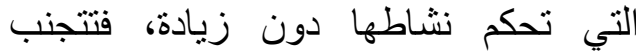
المنظمة أية متابعات قضائية، فتلتزم بتطبيق قوانين العمل والضرائب ومعايير المحافظة

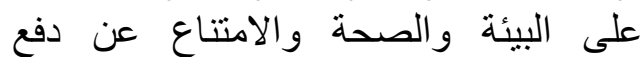
الرشناوى و المحاباة. positive and competitiveness was positive and strong in most indicators. strong in most indicators.

Therefore the countries which undertake to respect the principles of the RS become more competitive, in contrast to countries that marginalize it. So the countries where the principles of social responsibility are less respected have interest to mitigate the negative effects thereof, to benefit from the experience of other countries and to give a better image of Islam and Muslims.

ففي هذه الحالة لا تقدم المنظمة سوى الحد الأدنى من القيمة التي يحصل عليها

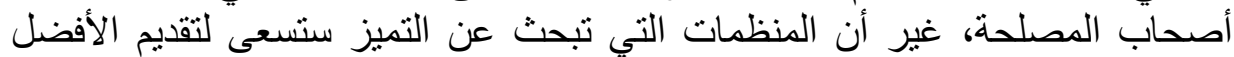
وسترتقي للمستوى الأخلافي في تطبيق المسؤولية الاجتماعية ما يعطيها ميزة تنافئية، لذا قامت العديد من المنظمات الدولية بوضع مبادئ للمسؤولية الاجتماعية يفترض الأية التقيد بالعمل بها لضمان تحقيق المصلحة للجميع.

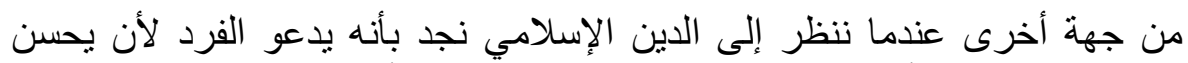

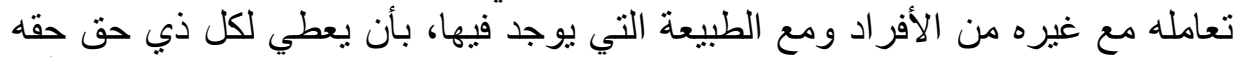

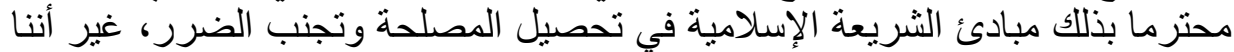

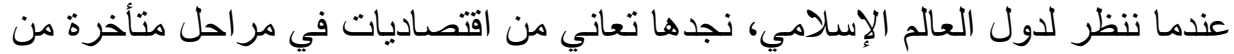
التنمية، تظهر في ضعرف التنافية.

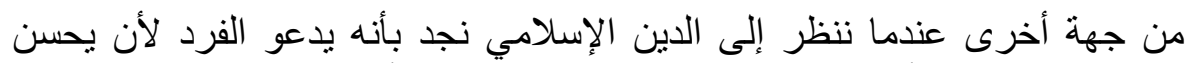

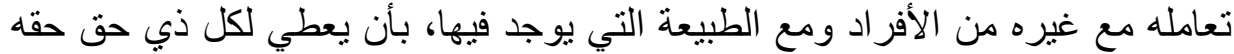

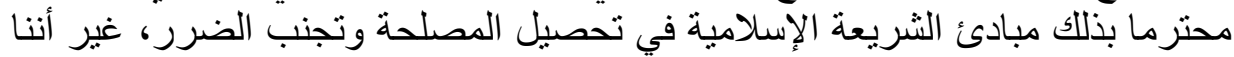

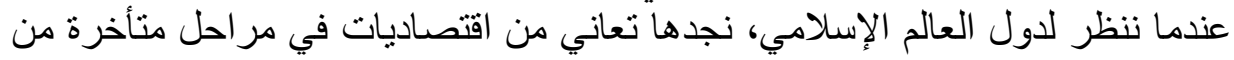

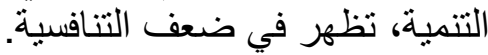
وبذلك نطر ح إثنالية البحث:

ما طبيعة العلاقة بين المسؤولية الاجتماعية وتتافسية اقتصاديات دول العالم الإسلامي؟ للإجابة على هذا السؤال نطر ح مجمو عة من الأسئلة الفرعية تتمثل في:

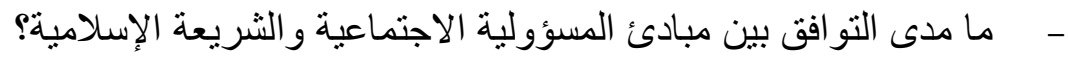

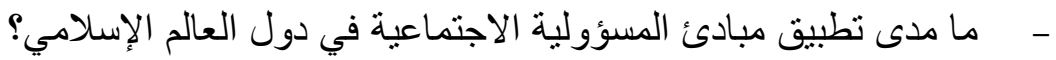

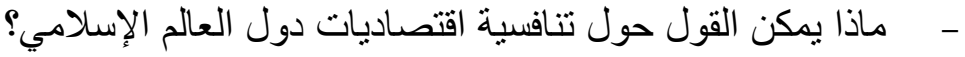


وللإجابة على الإشكالية المقدمة ستعتمد الدراسة على فرضية أساسية مفادها بأن الإن إنانة دول العالم الإسلامي تطبيق المسؤولية الاجتماعية بشكل بسمح لإليد بتحسين تنافسية

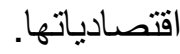

لاختبار هذه الفرضية سنعتمد على منهج وصفي نبين فيه مستويات الالتزام بالمسؤولية الاجتماعية لعينة من دول العالم الإسلامي كما سنشرح مدى تنافينة فئهية قطاع

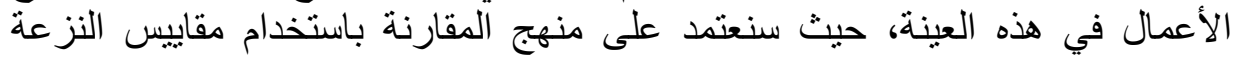

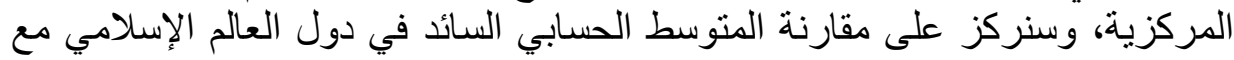
المتوسط الدولي، بعدها سنحلل معامل الارتباط بين مؤشراتئ الثرات المسؤولية الاجتماعية

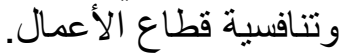

و عليه سنقسم الدراسة إلى خمسة محاور، المحور الأول سنناقش فيه ظهور

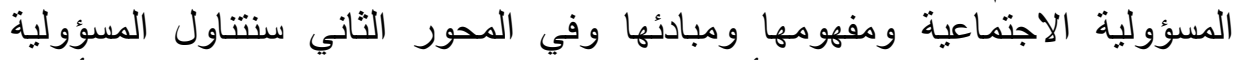

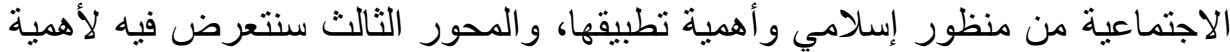

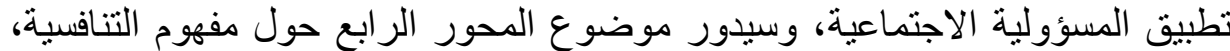

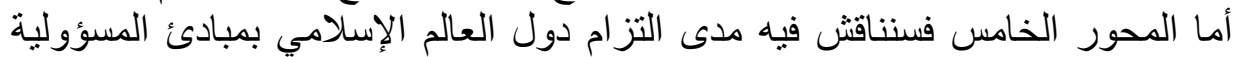
الاجتماعية و علاقة ذلك بتتافسية قطاع الأعمال.

\section{المحور الأول: الإطار النظري للمسؤولية الإجتماعية}

سيتناول هذا المحور ظهور المسؤولية الاجتماعية ومفهومها لاى المفوضية الأوربية ومنظمة الإيزو بعدها مبادئ المسؤولية الاجنماعية وفقا لمنظمة الأمية المم المتحدة.

\section{1- ظهور مصطلح المسؤولية الاجتماعية}

يعود مفهوم المسؤولية الاجتماعية إلى سنة 1953 (Carroll A. , 1999) حينما

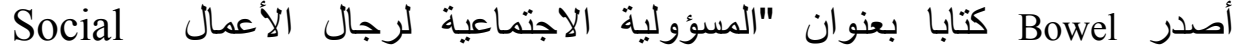
فesponsibilities of the Businessman فيه اقتصاديات دول العالم الإسلامي لا تزآل تحت وطأة آلاستعمار أو حديثة عهر

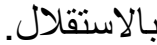

ويمكن القول بأن ظهور هذا المفهوم، هو كرد فعل على ما كان الفكر الرأسمالي

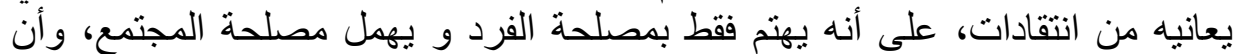

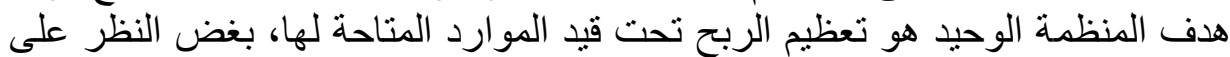

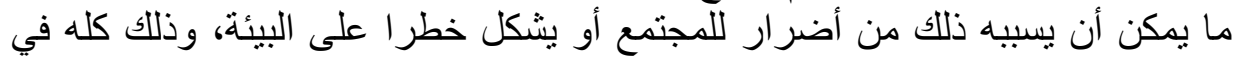
كون المنظمة كيان اقتصادي.

وأمام هذا النقص في الرؤية ظهرت مدرسة العلاقات الإنسانية التي دعت إلى دئ دافي

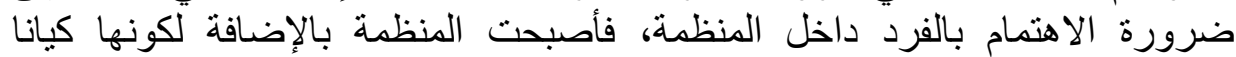
اقتصاديا تمثل كيانا اجتماعيا، يعمل على إنباع حاجة المساهمين بتعظيم الأرباح 


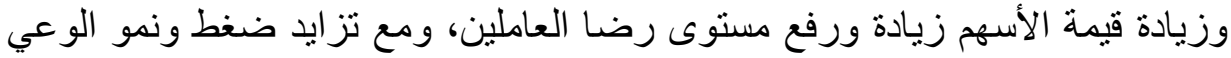

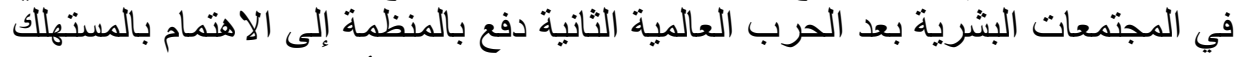

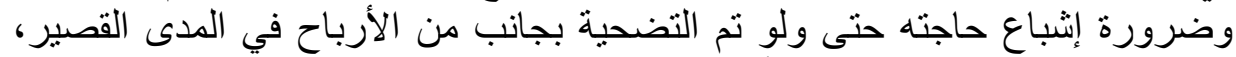

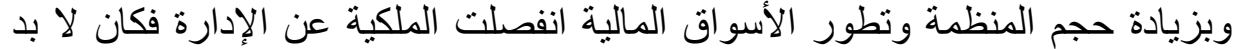

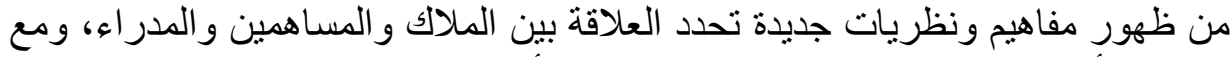

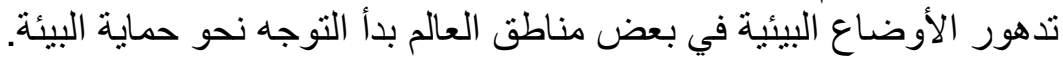

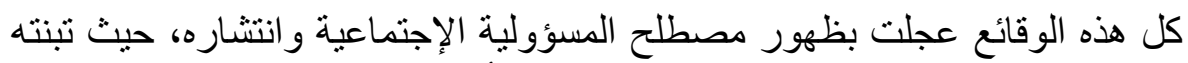
المنظمات الدولية والإقليمية، والبعض منها ظهر العهات أساسا ليرسخ تطبيق مبادئها مثل

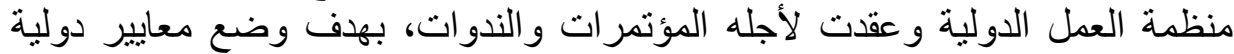
موحدة تلتزم بها الدول و المنظمة (Duane, 2013).

\section{2- مفهوم المسؤولية الاجتماعية}

وفقا للمفوضية الأوروبية (Commission Européenne, 2011) هي مسؤولية المنظمة أمام تأثثيرات نشاطها على المجتمع، و لأدائها ينبغي على الماتى المنظمة احترام

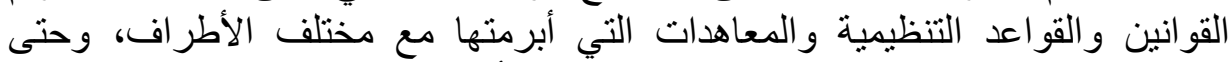

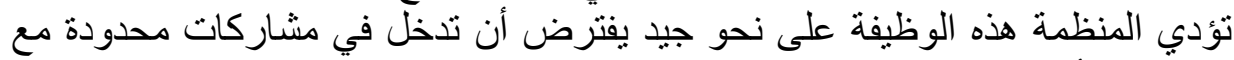

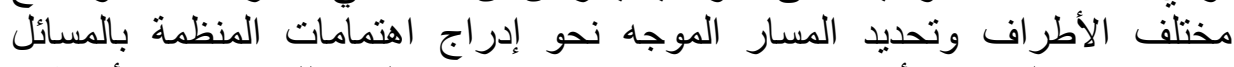
الاجتماعية والبيئية والأخلاقيات واحتر ام حقوق الإنسان و المستهلك سواء في أنشطتها

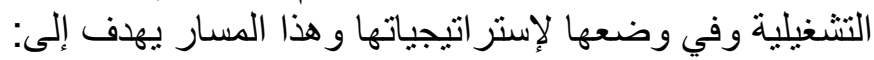

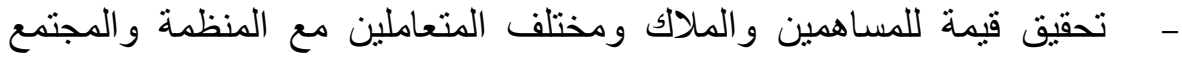
كکل؛

- - مصر وتوقع وتقليص كل الآثار السلبية التي يمكن أن تتسبب فيها المنظمة.

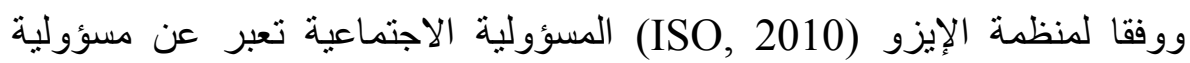

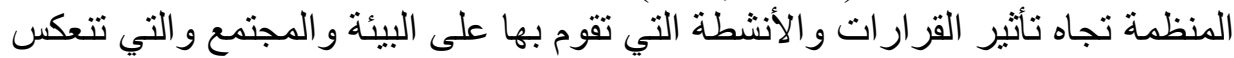
على سلوك خلقي وشفاف يؤدي إلى نئ:

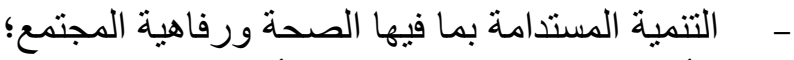

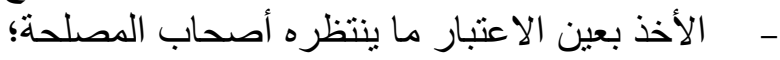

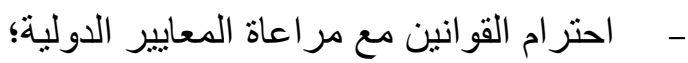
- - معلها ضمن ثقافة المنظمة و علاقاتها.

يركز تعريفي المفوضية الأوروبية ومنظمة ISO على أن المسؤولية الاجتماعية

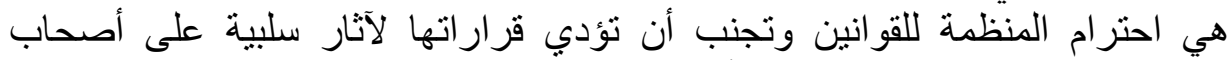

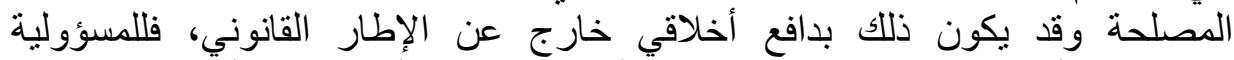
الاجتماعية أفق يتعدى النظرة القانونية للأمور، باعتبار أن للقانون أفق ضيق، فئ فهو 
يستمد مواده من السلوك الذي يظهره أصحاب المصلحة تجاه القرارات التي تتخذها

المنظمة مونمة

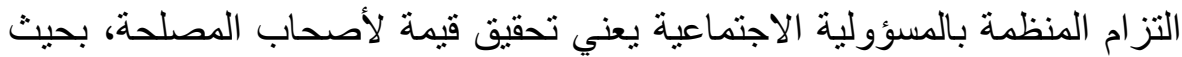

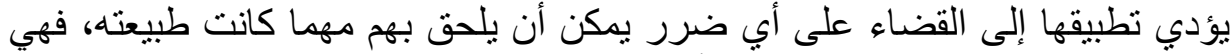

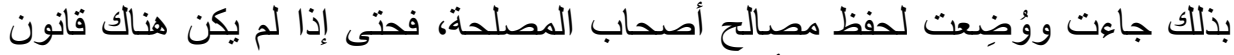

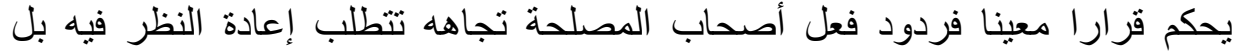
و إعادة النظر في القوانين وصياغتها ورد وإضافة قو انين جديدة.

فتطور المسؤولية الاجتماعية هو نتيجة تغير محيط المنظمة ولئه ولاقتها بأصحاب المصلحة، ما دفع الباحثين لوضع أشكال لهذه المسؤولية، فقام (Carroll A. B., 1991)

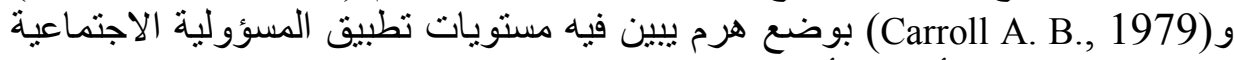

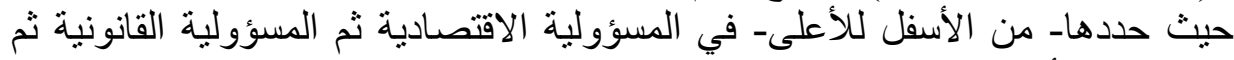
المسؤولية الأخلاقية ثم المسؤولية الخيّرِة.

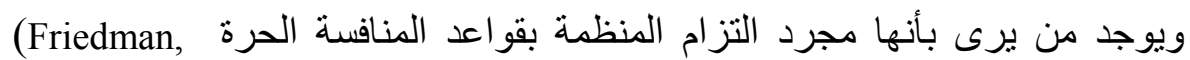

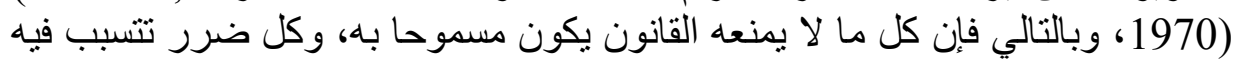

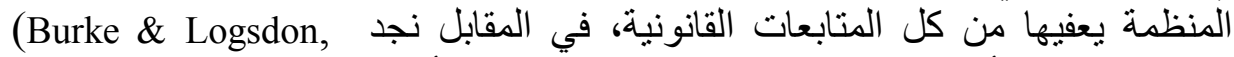

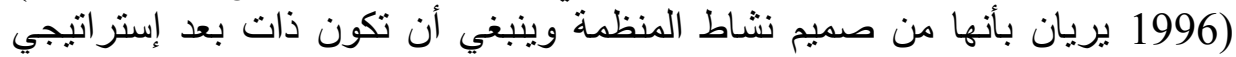
بحيث تتصف بالمركزية و الإرادة الطوعية والثفافية والاستشر اف و الخصوصية بمان يعطي للمنظمة ميزة تنافسية.

وبالعودة لواقع المنظمة نجد أن البعض منها يأخذ المبادرة في تطبيق مبادئ

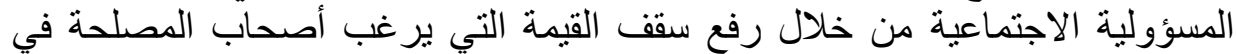

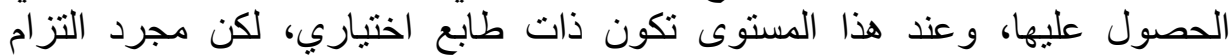

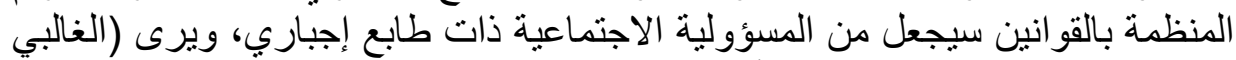

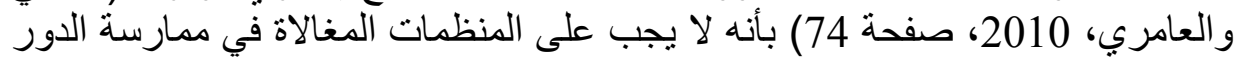

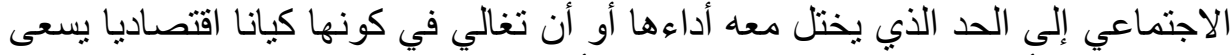
فقط لتحقيق الأرباح، وبينها يفترض بالمي المنظمة أن تجد مدخلا وسطا.

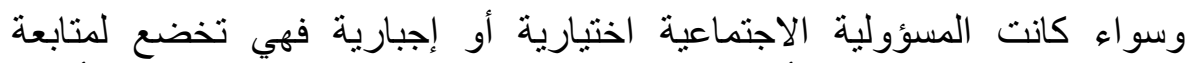

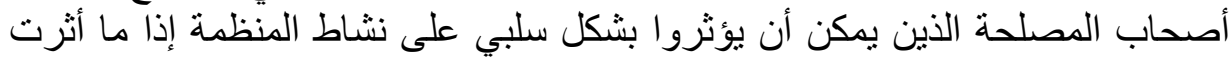

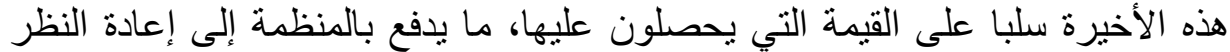

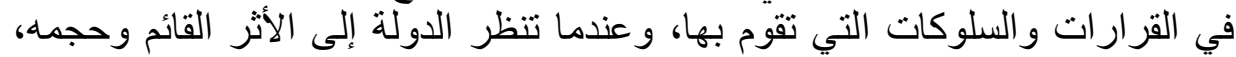

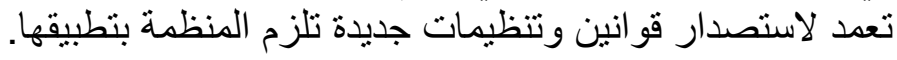

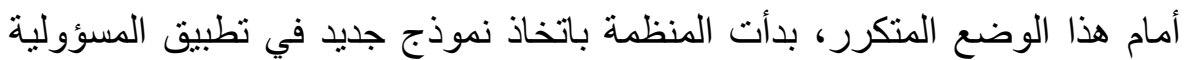

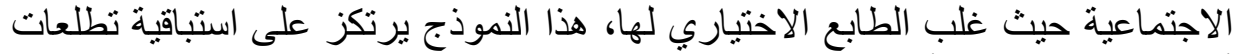
أصحاب المصلحة، أي على الإبداع، وعند هذا الإني المستوى لم تعد المنظمة سبيا في 
المشاكل ولكن طرفا في الحل. ولتكريس تطبيق المسؤولية الاجتماعية وتشجيع

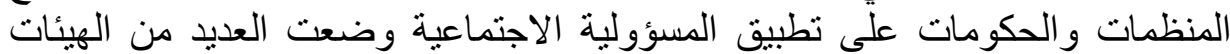

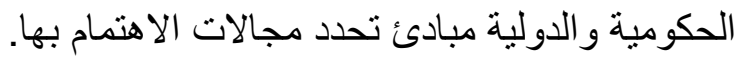

3- مبادئ المسؤولية الإجتماعية

صنفت الهيئات الدولية والإقليمية مثل (Commission Européenne, 2011) (OCDE, 2001) ومنظمة الأمم المتحدة مبادئ للمسؤولية الاجتماعية، ضمن عدة الألية (200)

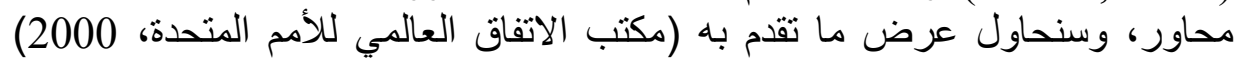
و التي حصر ها في عشرة مبادئ ضمن أربعة محاور هي: حقوق الإنسان

- - المبدأ 1: دعم حماية حقوق الإنسان المعلنة دوليا واحتر امها؛

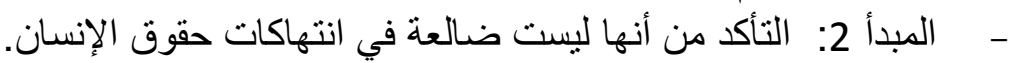

$$
\text { معايير العمل }
$$

- - المبدأ 3: احترام حرية تكوين الجمعيات والاعتراف الفعلي بالحق في

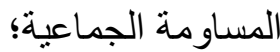

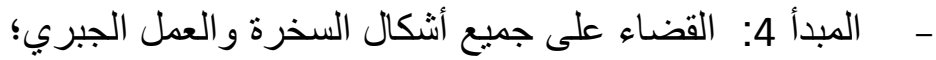

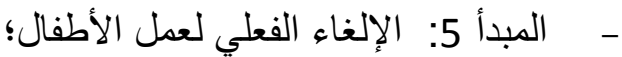
- - المبدأ 6: القضاء على التمبيز في مجال التوظيف والمهن.

البيئة

- المبدأ 7: التشجيع على اتباع نهج احترازي إز اء جميع التحديات البيئية؛ - - المبدأ 8: الاضطلاع بمبادرات لتوسيع نطاق المسؤولية عن البيئة؛

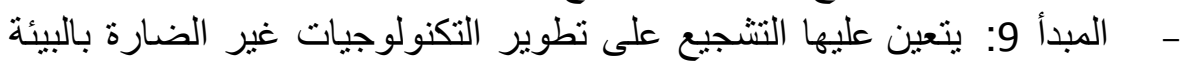

\section{مكافحة (لفساد}

- - المبدأ 10: يتعين على المنظمات التجارية مكافحة الفساد بكل أنثاله، بما فيها

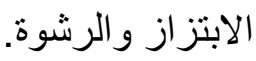

تمثل المسؤولية الاجتماعية بهذا الثكل الجانب الأخلاقي للأعمال سواء كانت التأت

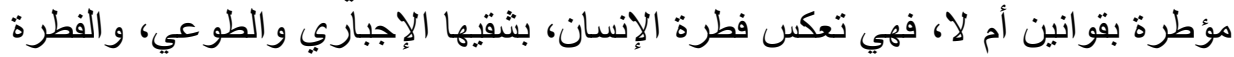


عندنا نحن المسلمين هي الإسلام، وهو ما سيتناوله المحور التالي، الذي سنبين فيه مدى تو افق هذه المبادئ مع الثنريعة الإسلامية. الشريعة الإسلاميةً: الثياني: تبيان التوافق بين مبادئ المسؤولية الإجتماعية مع مبادئ

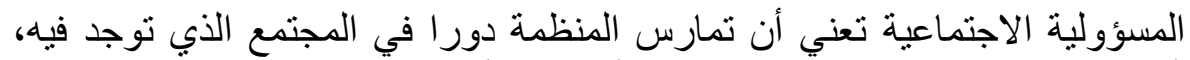

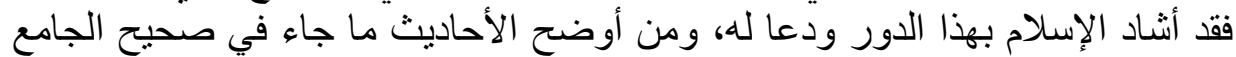

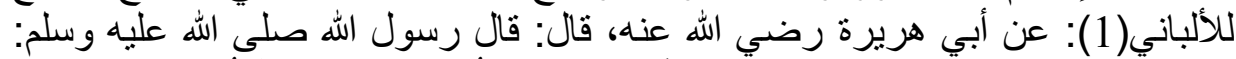

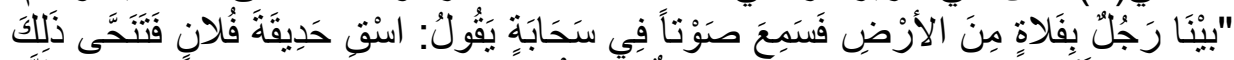

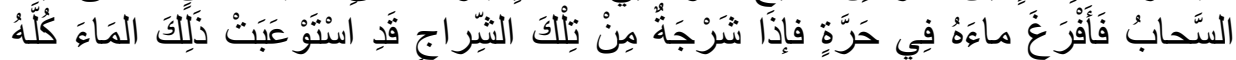

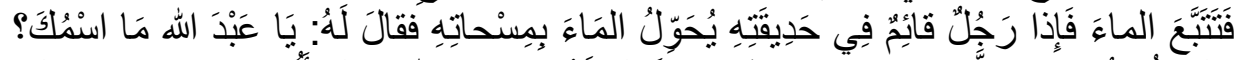

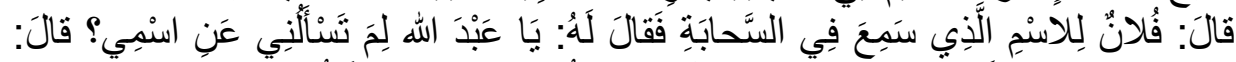

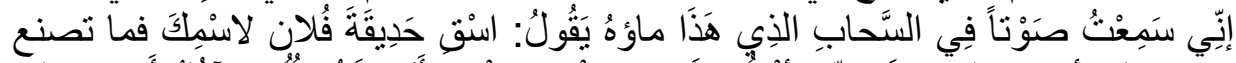

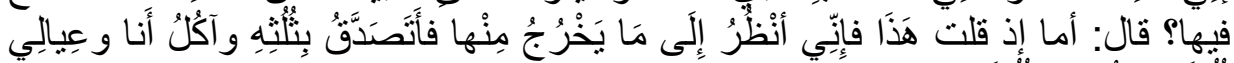

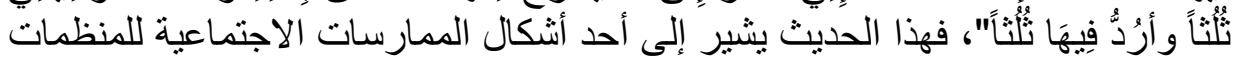
وأهمية مساهمة المنظمة فئاس في المجتمع.

ولقد أظهرت بعض الدر اسات مدى تو افق المسؤولية الاجتماعية -بمفهومها الحديث-

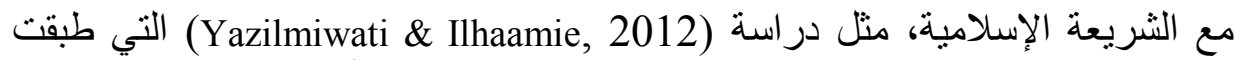

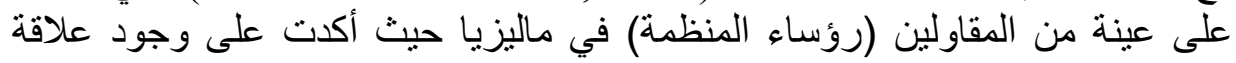

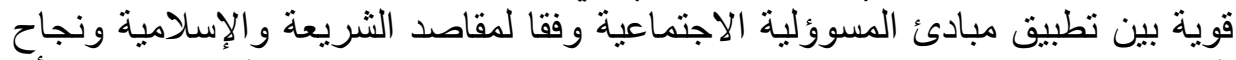

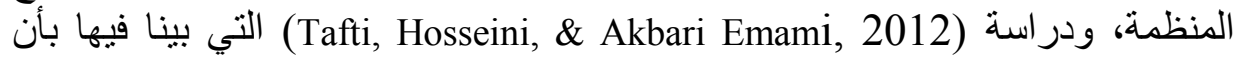
المجالات الأساسية للمسؤولية الاجتماعية تنحصر في قو اعد تنظيم العمل وسياسة البيئة

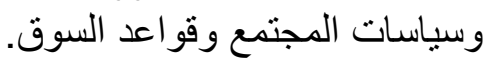

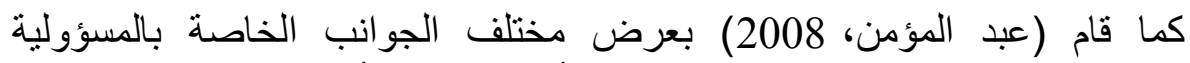

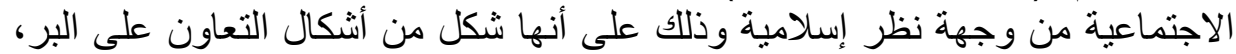

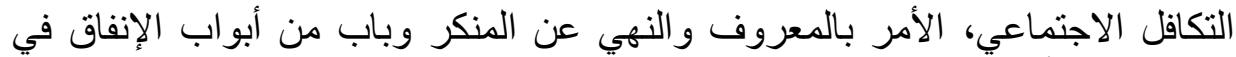

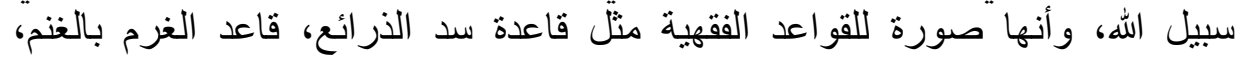

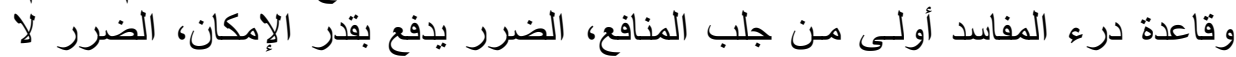

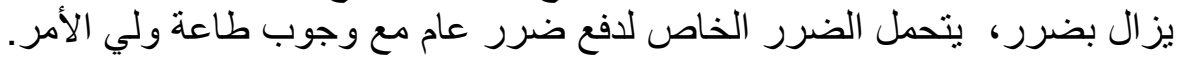
و لأن المسؤولية الاجتماعية في مستواها الأسمى يكون لها بعد أخلاقي، والإسلام

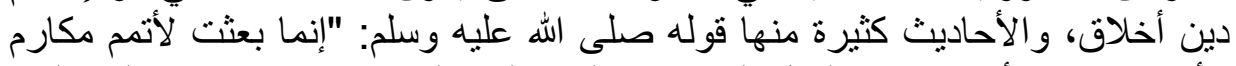

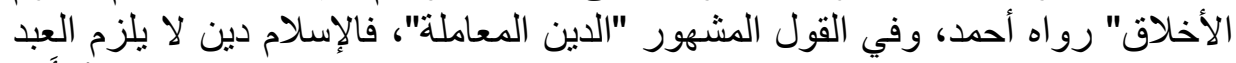

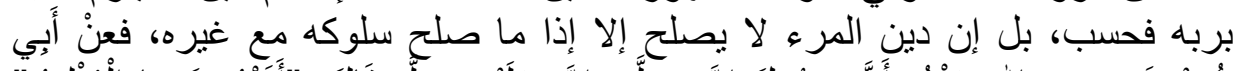

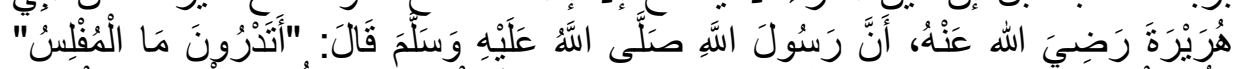

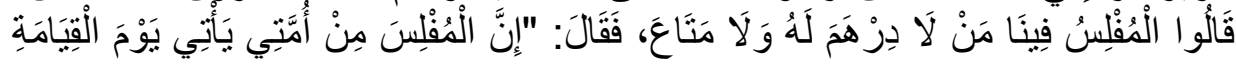




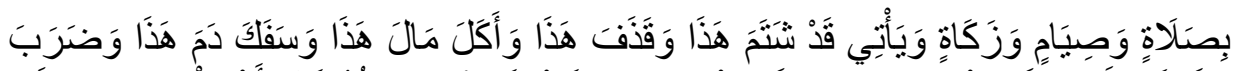

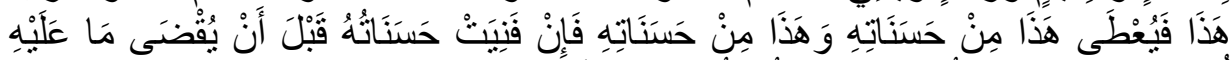

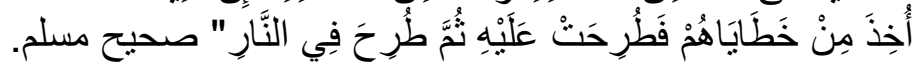

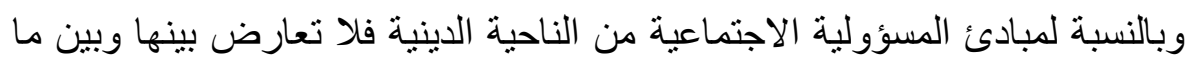

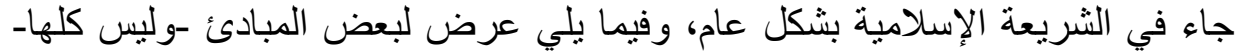
وفقا لماً جاء في الإسلام.

\section{1- 1 - 1العمالة والسخرة}

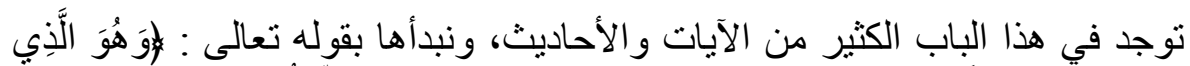

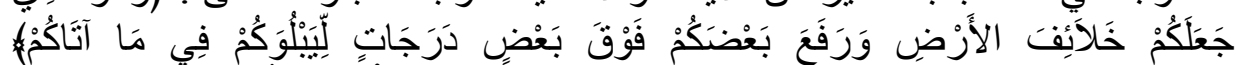

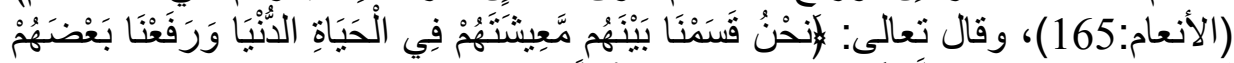

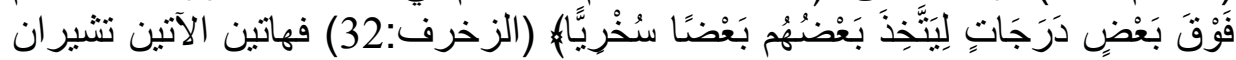

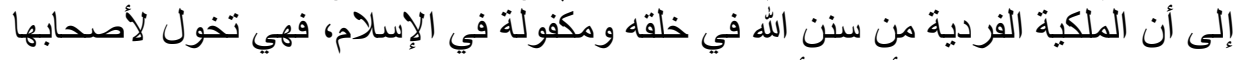

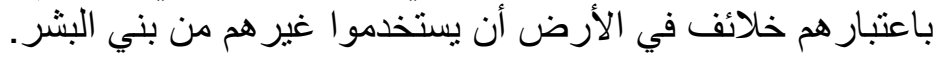

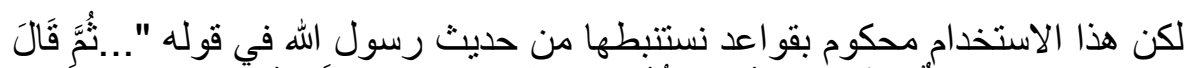

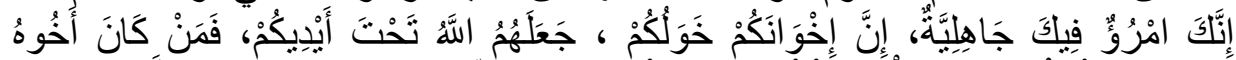

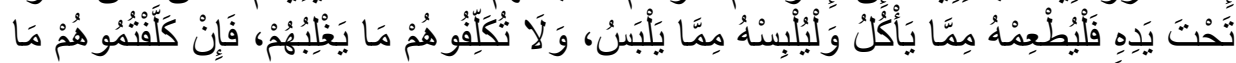

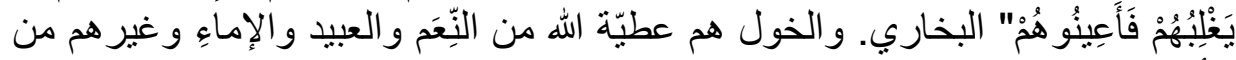

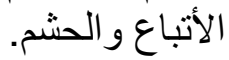

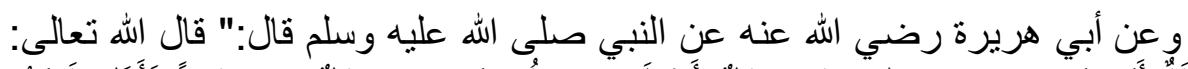

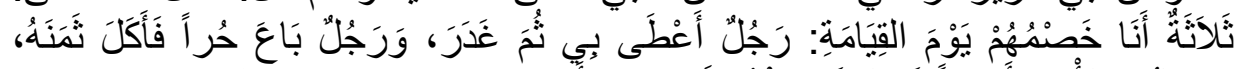

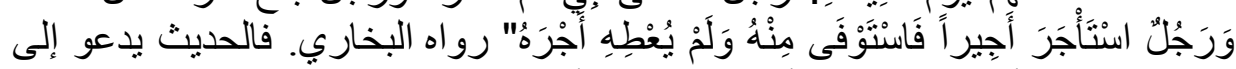

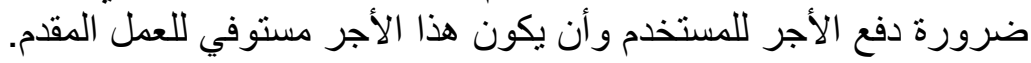

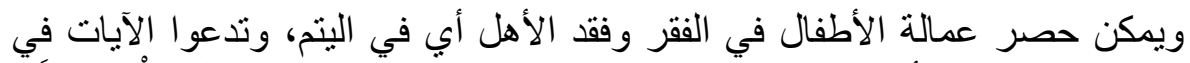

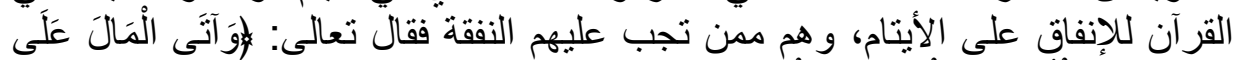

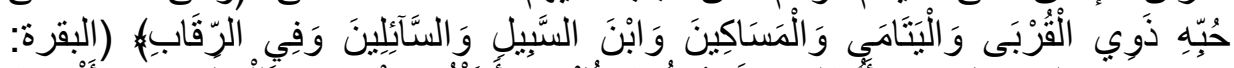

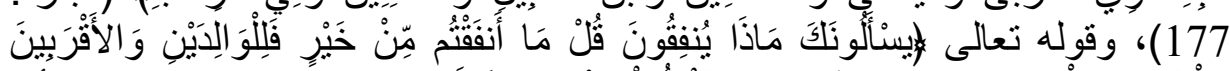

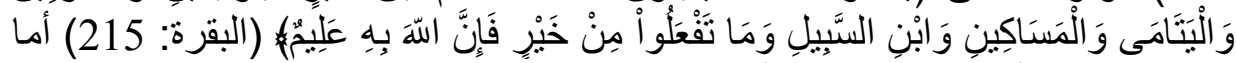

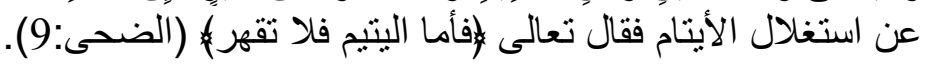

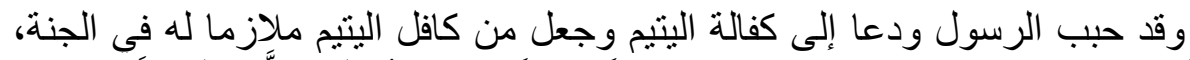

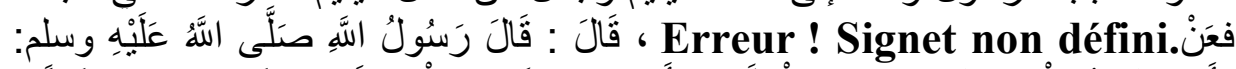

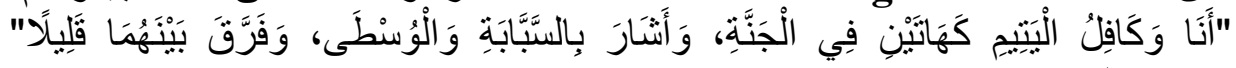




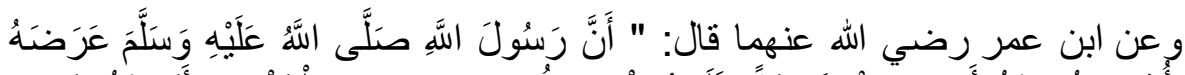

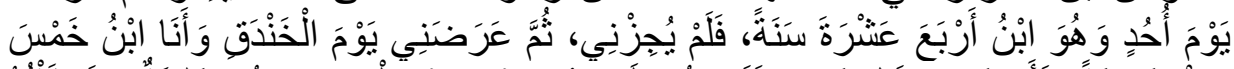

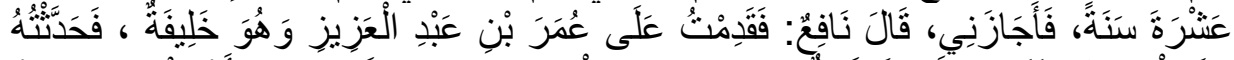

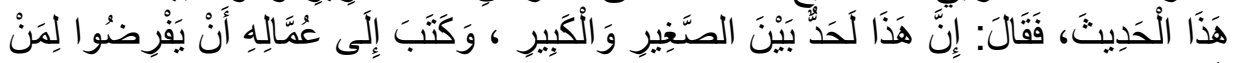

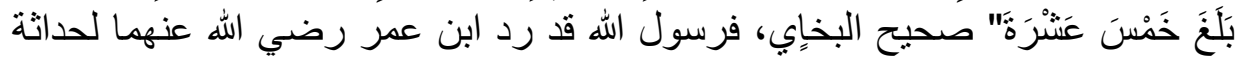

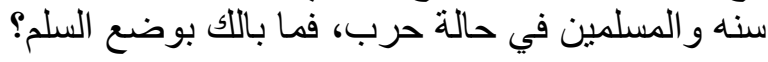

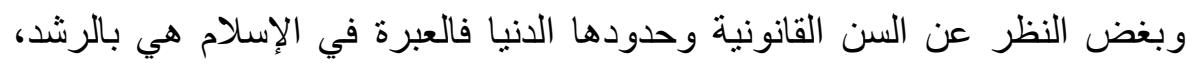

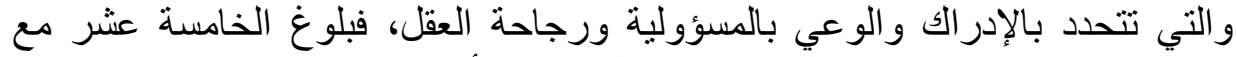

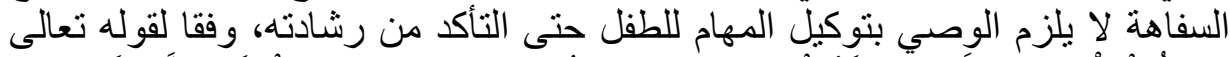

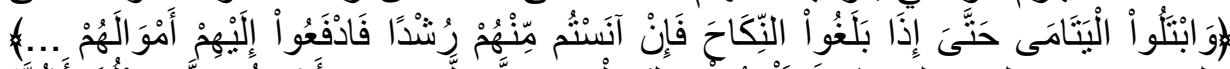

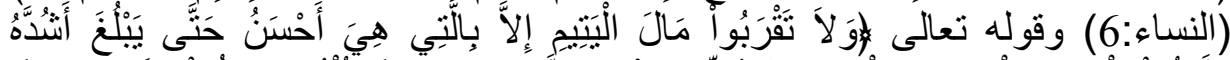

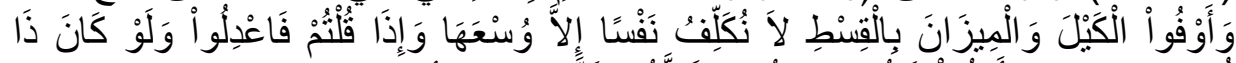

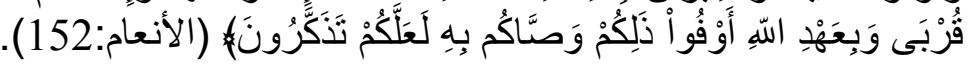

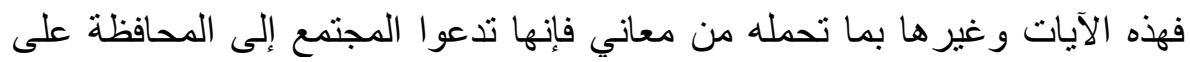

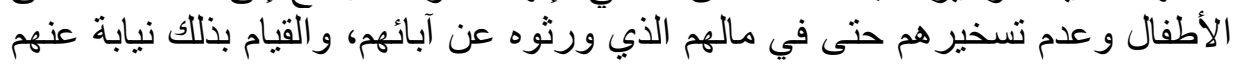

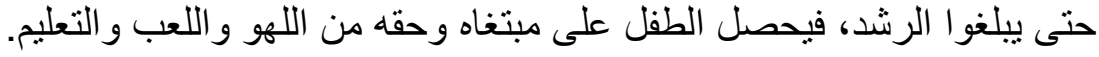

\section{2- مجال البيئة}

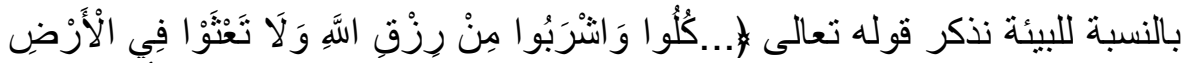

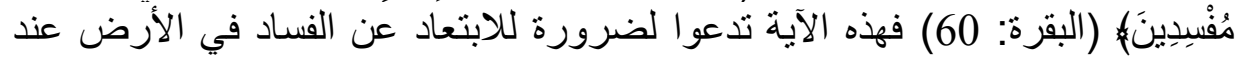

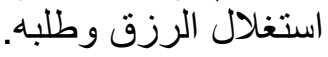

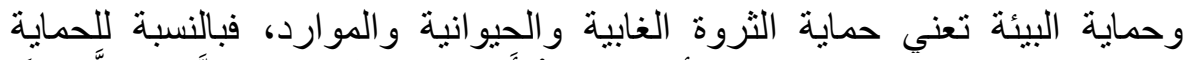

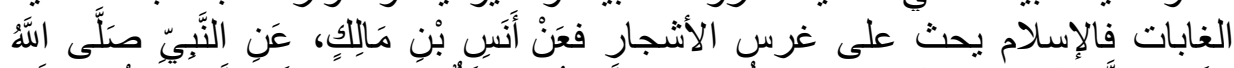

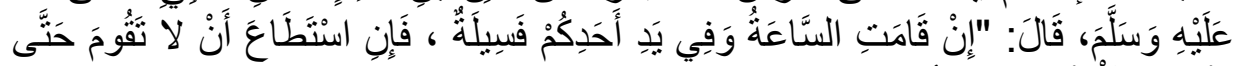

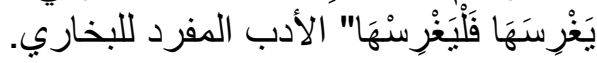

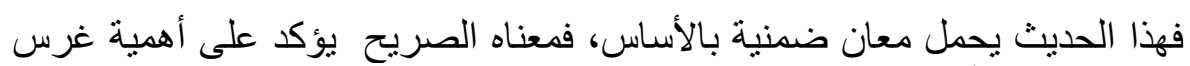

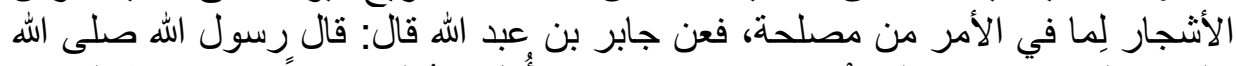

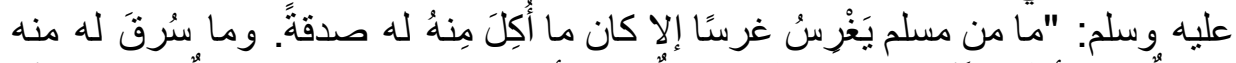

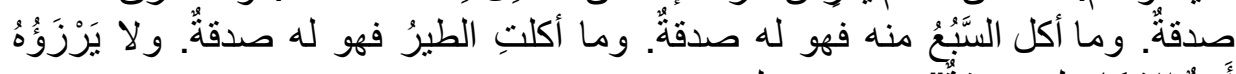

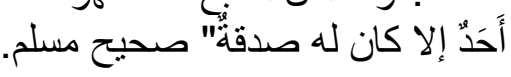

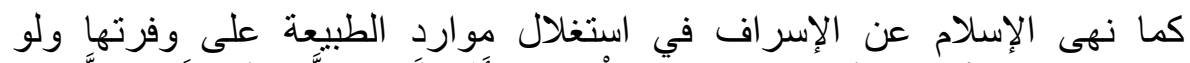

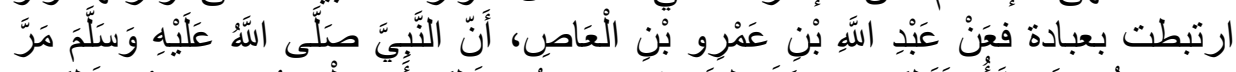

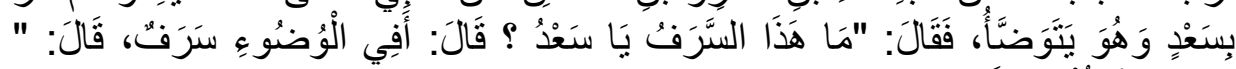

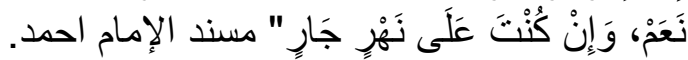


ويأمر الإسلام بالمحافظة على الثروة الحيوانية والرفق بالحيوان فعن عبد الله بن

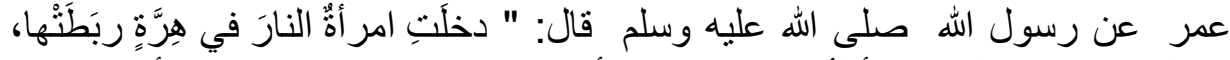

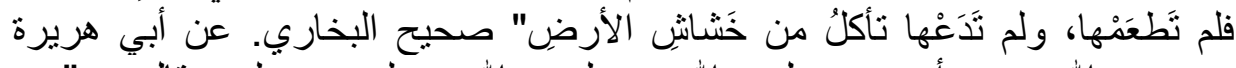

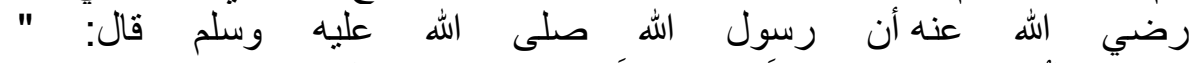

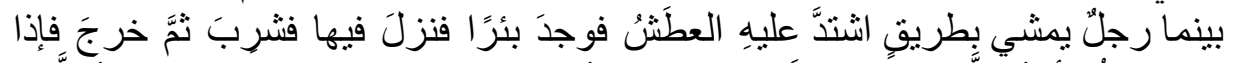

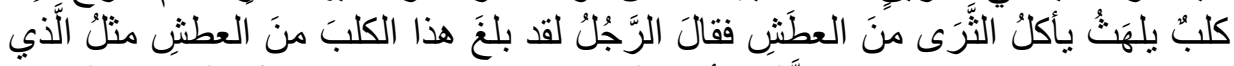

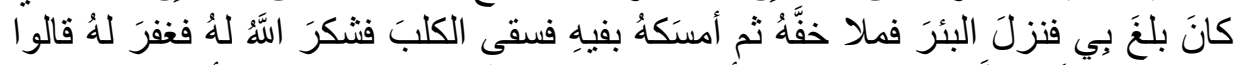

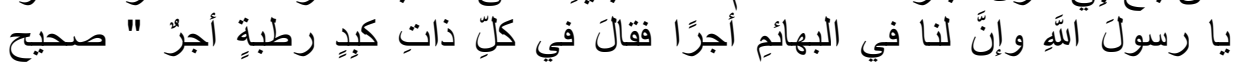
البخاري.

فالإسلام يدعو بموجب هذه الآيات و الأحاديث للمحافظة على البيئة في إطار سعي

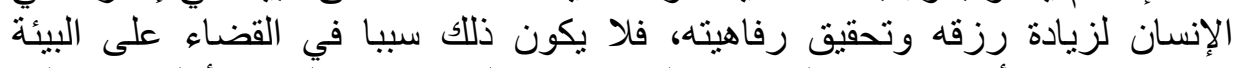

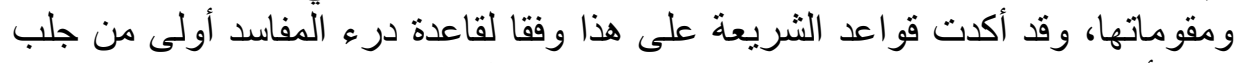

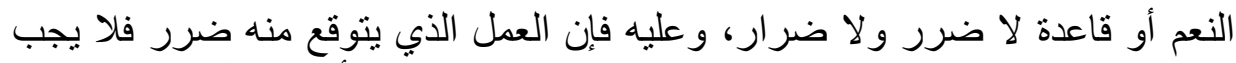

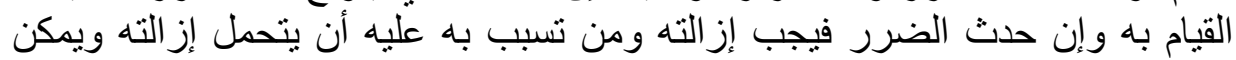
للدولة أن تضع وتسن القوانين لذلك.

و هذا يختلف مع الاعتقاد السائد بأن الديانات السماوية (Bron Taylor, 2004) بما

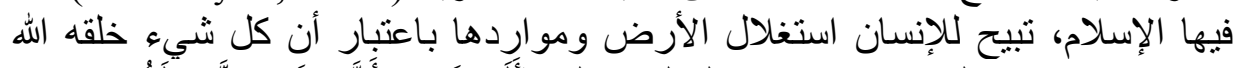

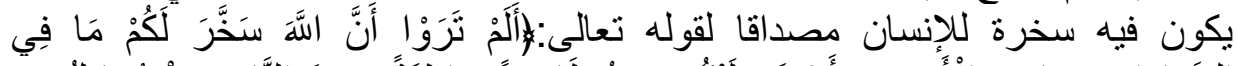

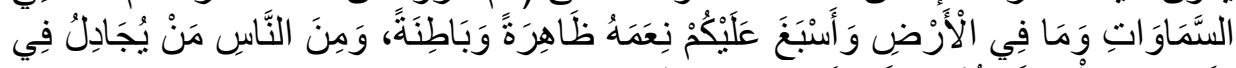

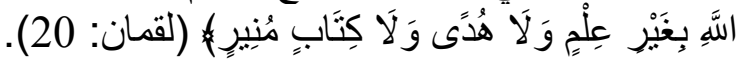

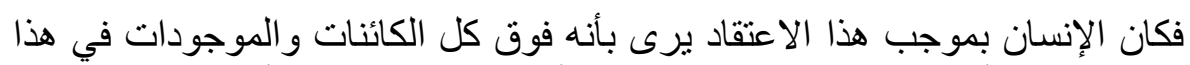

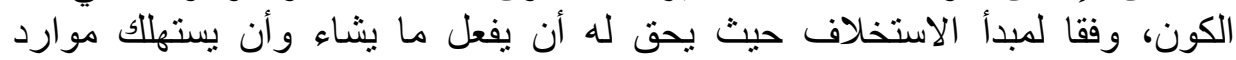

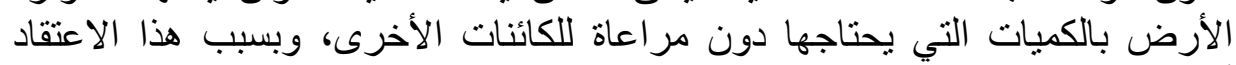

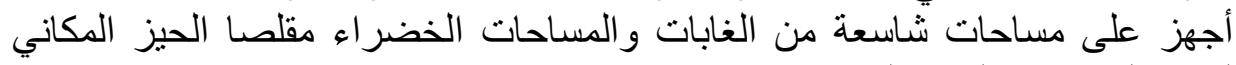
لعيش الحيو انات البرية التي انقرض عند عدد منها.

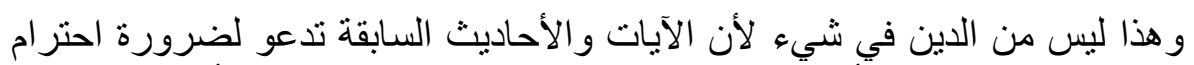

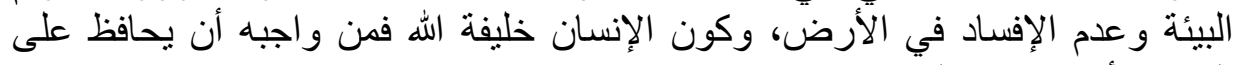

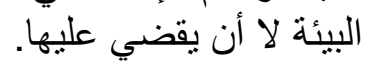

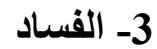

يقصد بالفساد في الفكر الاقتصادي التعاطي بالرشوة وتدخل السياسيين و المحسوبية،

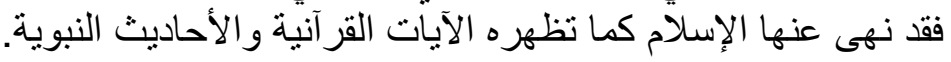




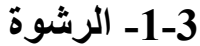

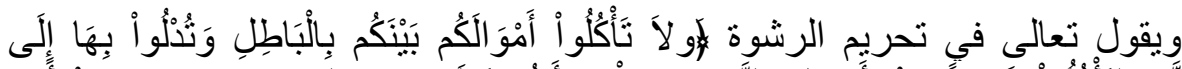

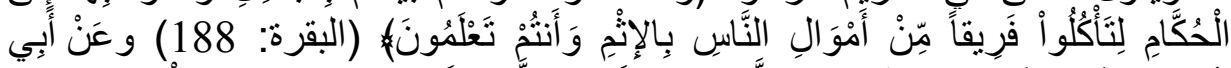

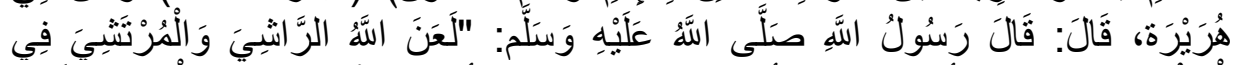

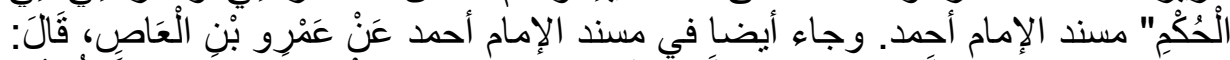

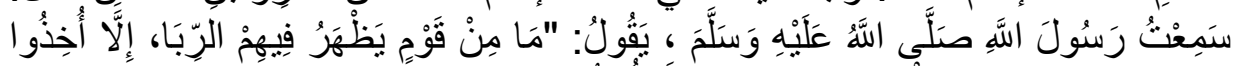

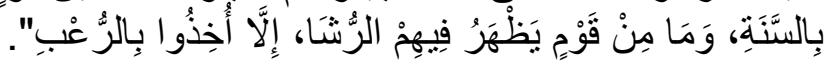

2-3 المحسوبية

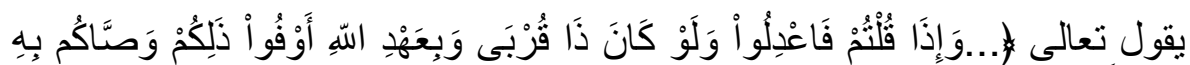

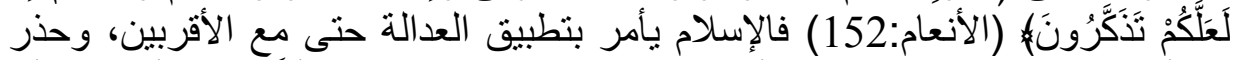

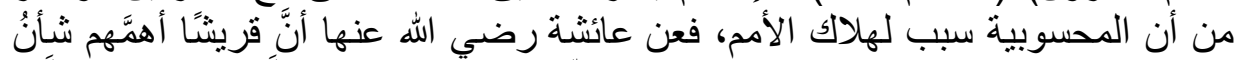

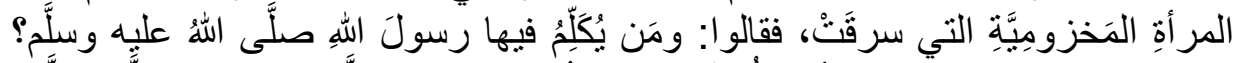

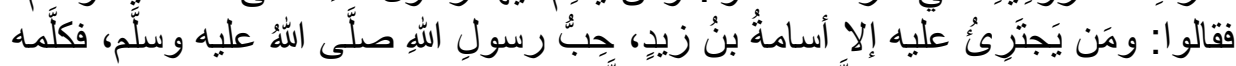

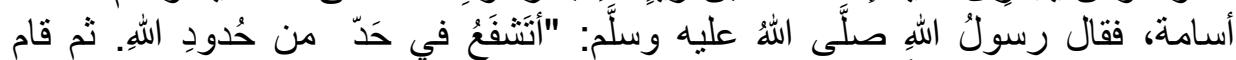

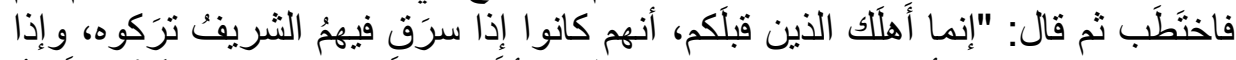

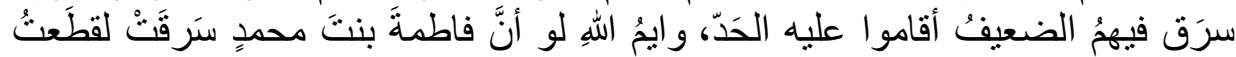

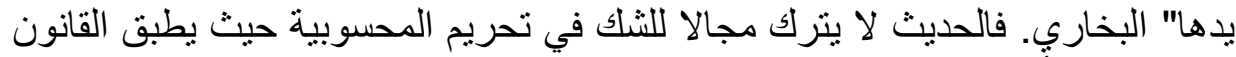

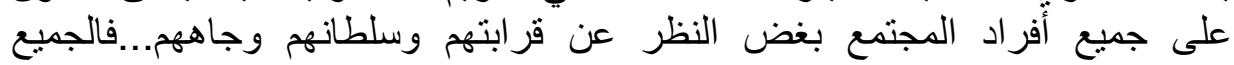

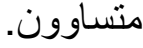

\section{4- احترام حقوق المستهلك}

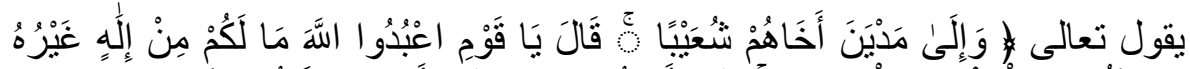

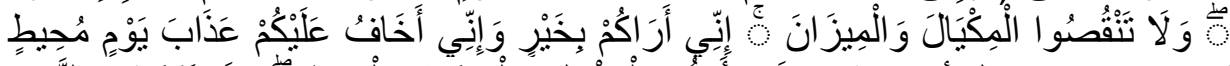

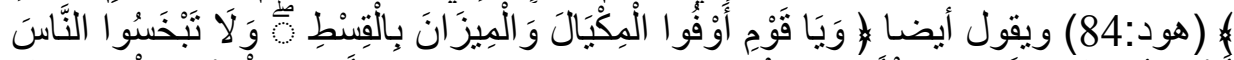

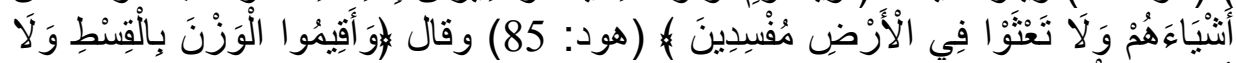

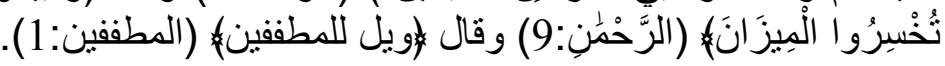

ومن خلال هذه الآيات والأحاديث النبوية لا يترك مجالا للثنك بأن الإسلام يضم

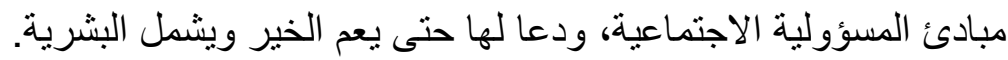

فاهتمام الإسلام بمبادئ المسؤولية الاجتماعية يرجع لعقود، لكن يبقى تطبيق مبادئها

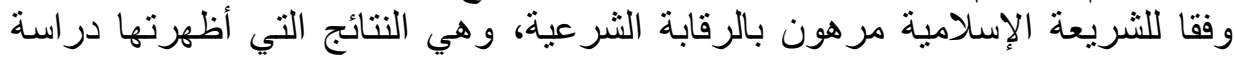
(Farook, Hassan, \& Lanis, 2011)

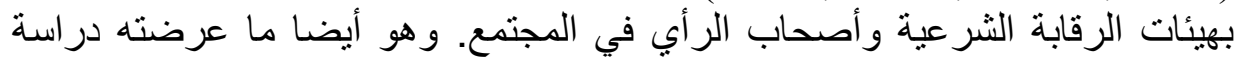
(Mallin, Farag, \& Ow-Yong, 2014) هيئات الرقابة الثرعية والإفصاح عن المسؤولية الاجتماعية للبنوك، وأيضا العلاقة لئة 
السببية بين الإفصاح عن المسؤولية الاجتماعية والأداء المالي والعكس بين الأداء

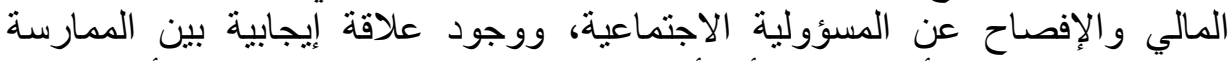

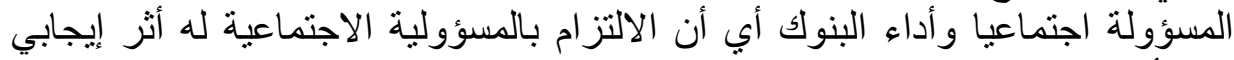

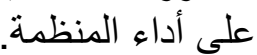

\section{المحور الثالث: أهمية الالتزام بمبادئ المسؤولية الإجتماعية}

إن تطبيق مبادئ المسؤولية الإجتماعية من منظور إسلامي يؤدي إلى عموم الخير

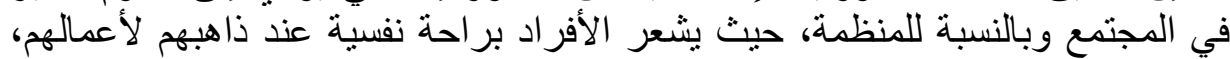

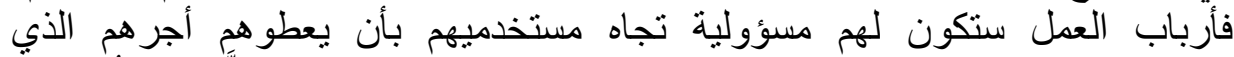

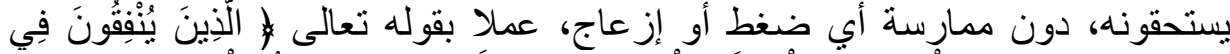

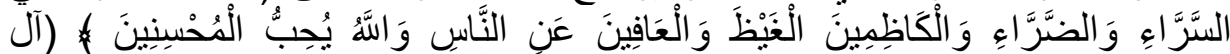

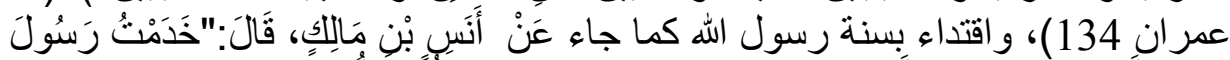

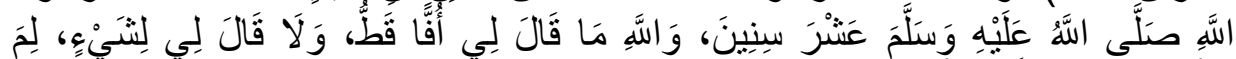

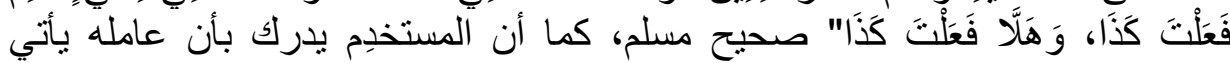

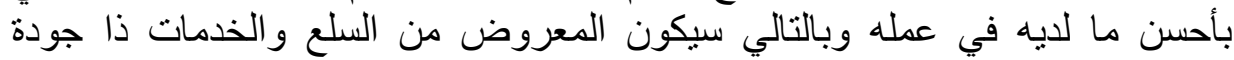
عالية.

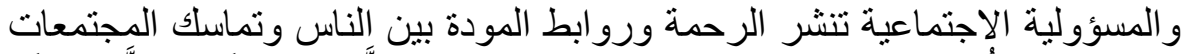

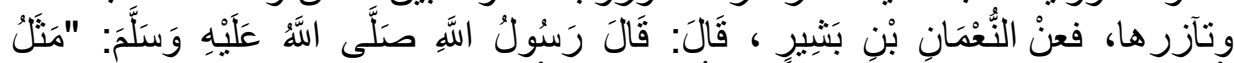

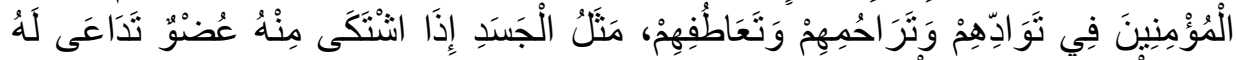

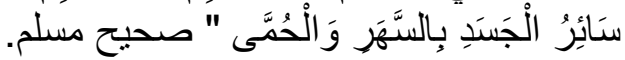

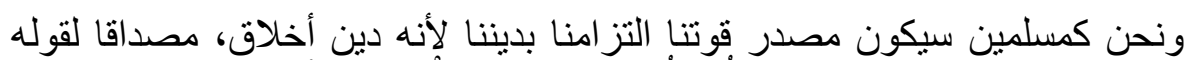

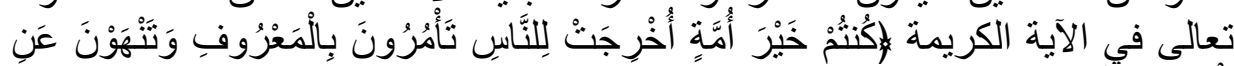

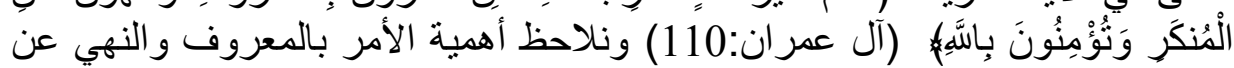

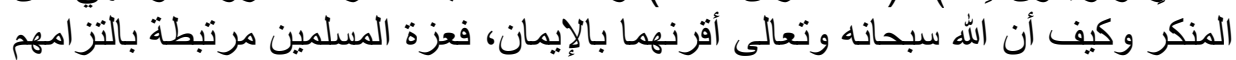

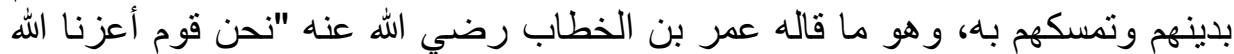
بالإسلام فإن ارتضينا العزة بغيره أذلنا الله".

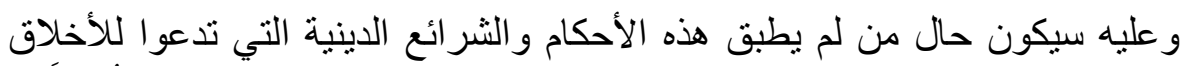

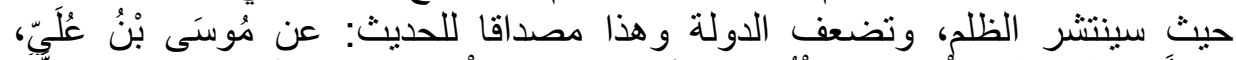

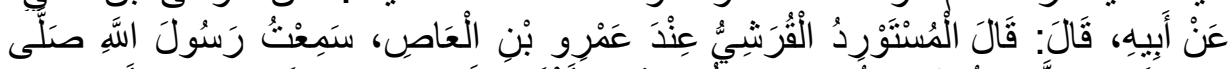

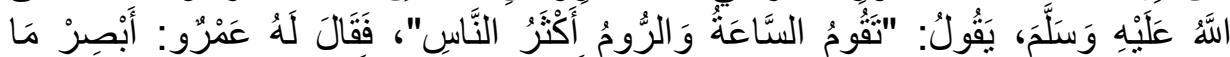

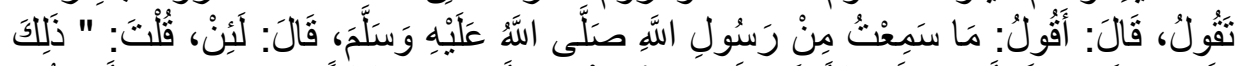

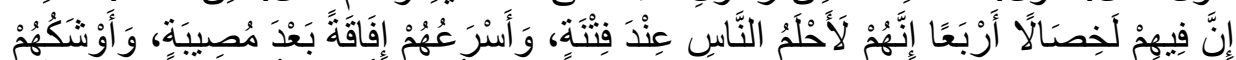

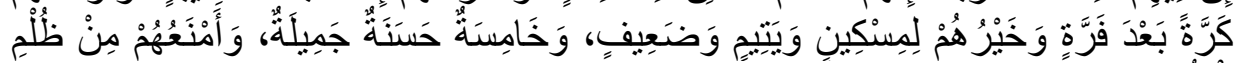

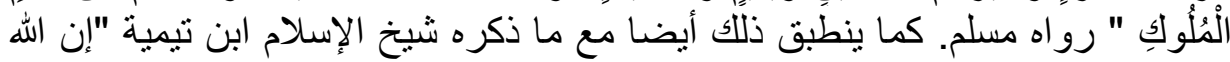

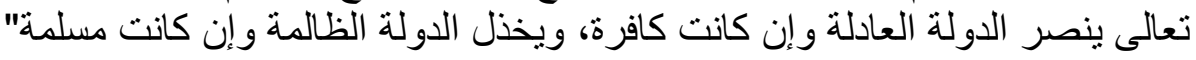


وقد جاء في المقدة (ابن خلدون، 2004، الصفحات 477-481) شواهد كثيرة حول أسباب خراب العمران وزوان فال الدول، وذكر من بينها الظلم والسخرة والاحتكار

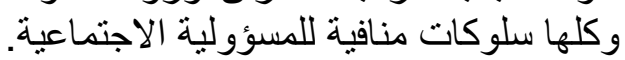

و وعليه فإن الابتعاد عن الأخلاق الحميدة سيضعف من قوة الدولة وقوة اقتصادها بحيث تضعف تنافسيته أمام تنافسية اقتصاديات الدول الأخرى، وكذللك الحال سيكون بالنسبة لقطاع الأعمال. ت تصغاف

وقد ذكرت الكثير من المقالات أهمية الالتزام بالمسؤولية الاجتماعية في تحسين

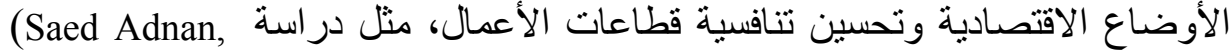
Abdul Rahim, \& Selvan, 2012) (Maden, Arıkan, Telci, \& الإجتماعية في تحسين كفاءة وأداء المنظمة، ودراسة الإنة الإنة Kantur, 2012) وصورتها وبالمقابل السلوك الجيد للعملاء و المستخدمين و المستثمرين.

و عدم الالتزام بمبادئ المسؤولية الاجتماعية يقودنا للحديث عن اللامسؤولية

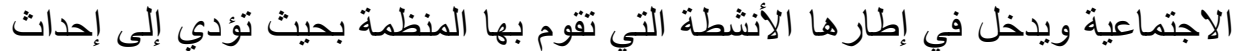

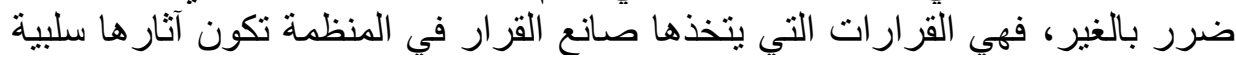

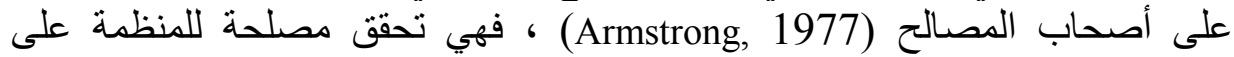
حساب النظام بشكل عام، كما يدخل في إطار اللامسؤولية الاجتماعية خرق المنظمة للقو انين.

ومن آثار السلوك اللامسؤول إجتماعيا هو تراجع صورة المنظمة وسمعتها

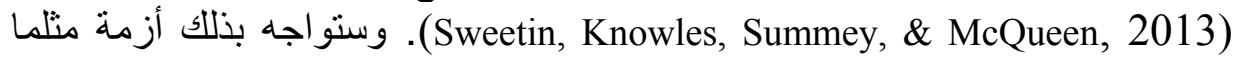
حدث مع شركة نايك NIKE في تسعينات القرن الماضي حينما كثف عن ممارساتها

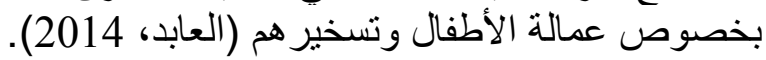

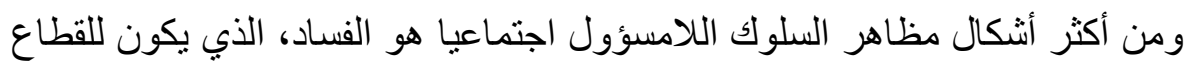

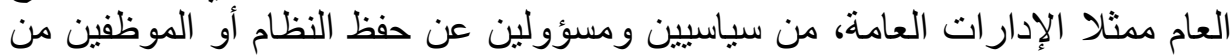

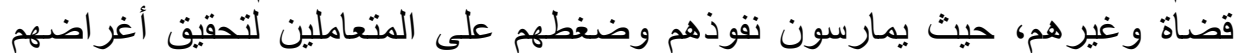

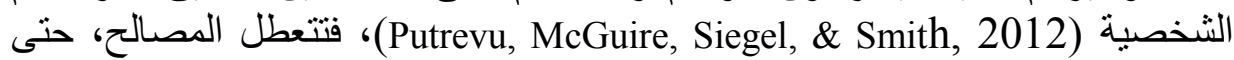
أن الفساد أصبح تكلفة ثابتة للمنظمات تدفعها لتسيير نشاطها.

ومن نتائجه السلبية حسب (Blackburn, Gonzalo, \& Puccio, 2009) هي القضاء

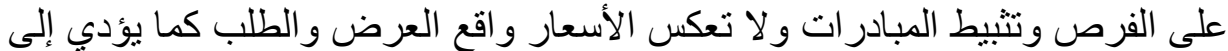

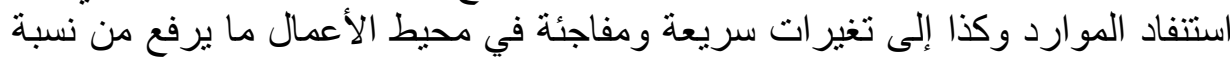

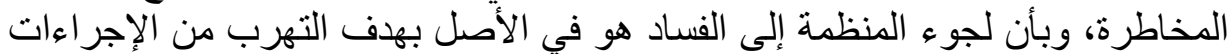

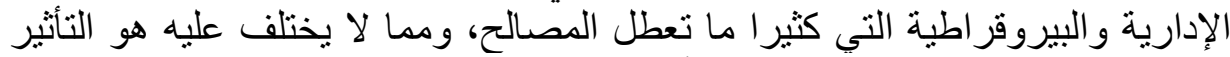

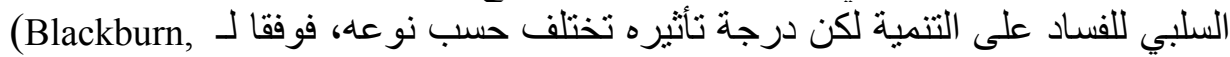


فإن الفساد الأكثر تنظيما يكون تأثثيره السلبي أقل من

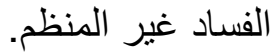

فالفساد باعتباره سلوكا غير مسؤول اجتماعيا، بمختلف أشكاله ومهما كان المجال

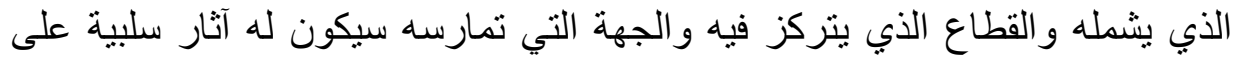
النشاط الاقتصاد وتر اجع تنافسية قطاع الأعمال.

\section{المحور الرابع: مفهوم التنافسية}

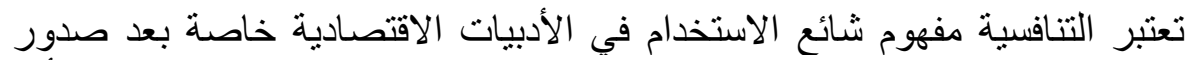

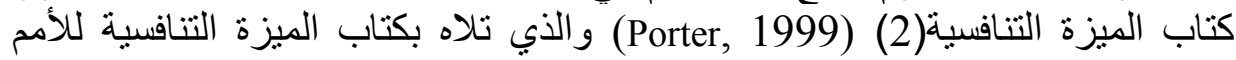
(Porter, 1993) حيث يعتبر المصطلح بديلا للميزة النسبية التي جاء بها دايفيد

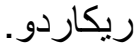

و تنقسم التنافسية إلى ثلاثة مستويات هي تنافسية الدولة وتنافسية الصناعة وتنافسية

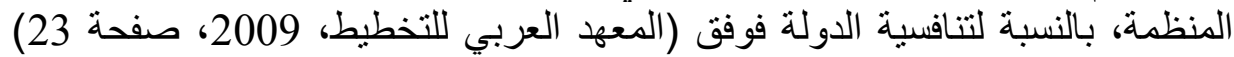

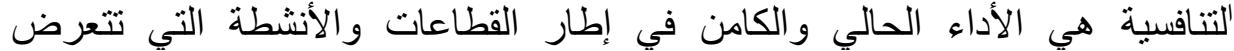

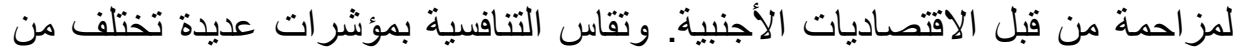

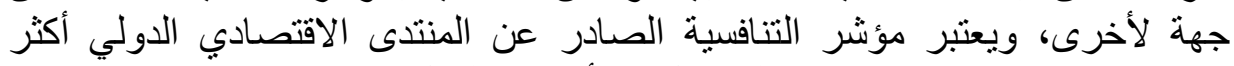
شمولا من حيث عدد المؤشرات المعدول بها أو عدد الدول التي يتم قياس تتافسيتها.

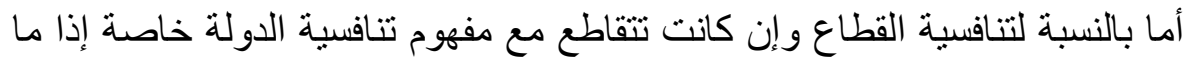

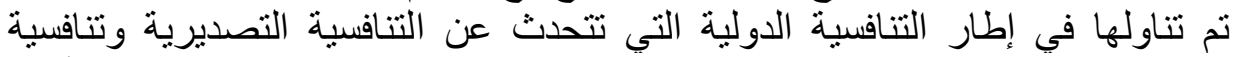

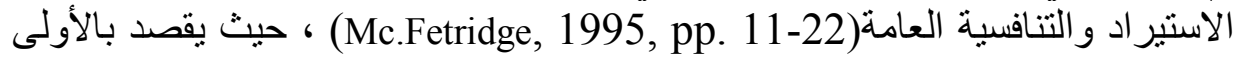

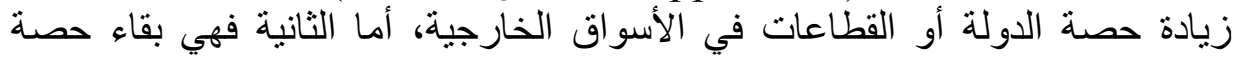

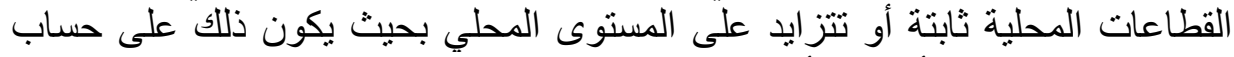

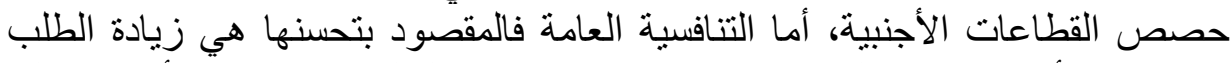

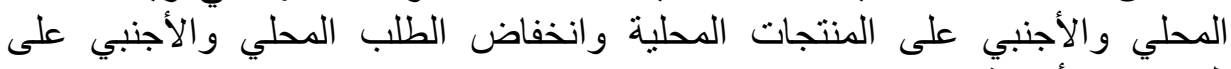

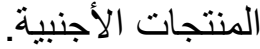

أما تنافسية المنظمة ووفقا لـا (BCG, 1980, p. 33) فهي تعبر عن قدرة المنظمة المافة

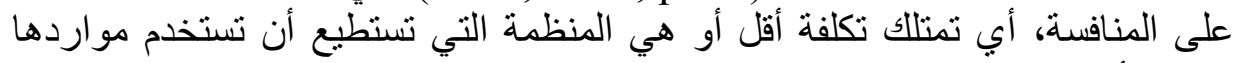

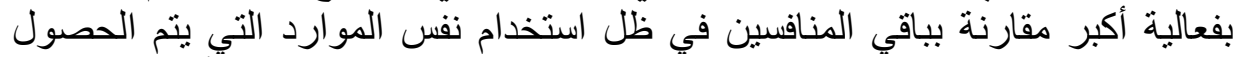

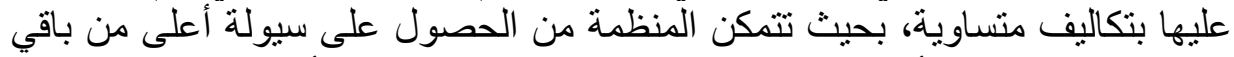

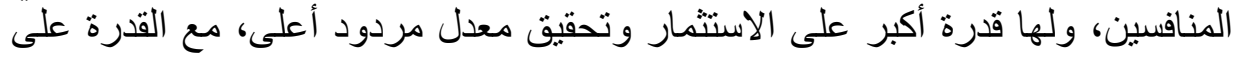
البقاء والمقاومة في حالة نراجع السوق مع الاستمر ار في تحسين ميزة التكلفة.

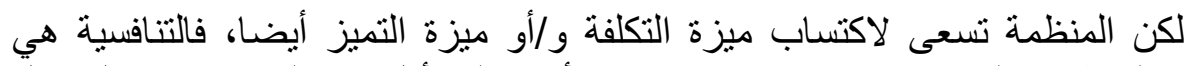

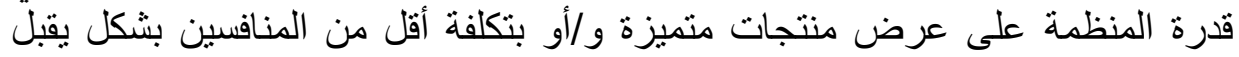
معه العملاء على منتجات المنظمة ويسمح لها بالحصول على على عوائد تضمن بقائها 


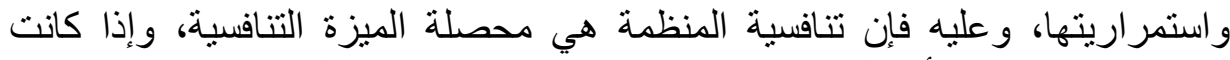
للمنظمة في قطاع الأعمال قدرة تنافسية فإن هذا سينعكس بشكل إيجابي على تنافسية القطاع.

إن العلاقة الموجودة بين مستويات التنافسية الثلاث تعتبر وثثقة بحيث تشكل سلسلة من ثلاث حلاقات إذا ضعفت إحداها ضعفت الأخرى، ولقد ذكر (Porter, 1990) بأن

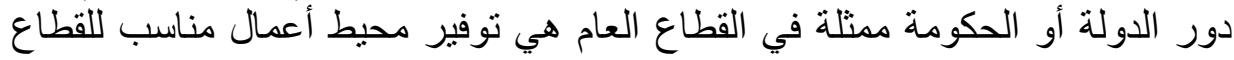

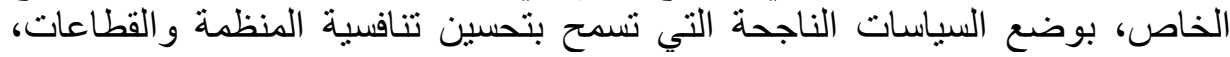

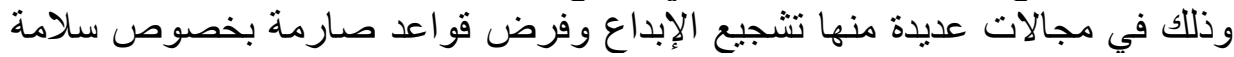
المنتجات ومعايير المحافظة على البيئة وتنظيم قو اعد المنافسة ومنع الاحتكار ات.

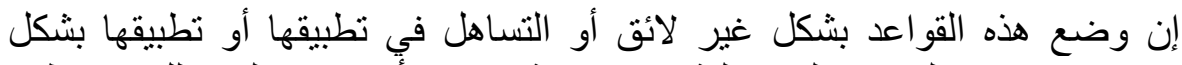

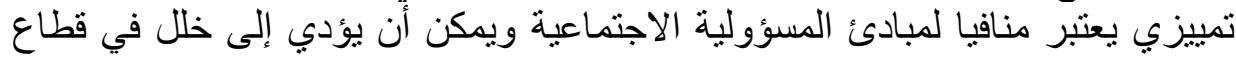

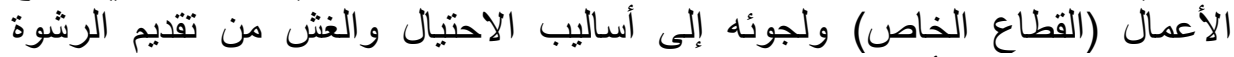
ومحاباة المسؤولين أي إلى سلوكات منافية لمبادئ المسؤولية الاجتماعية ولثريعة التئة التئية الإسلام، بدلا من السعي نحو تحسين تنافسيته.

المحور الخامس: تحليل العلاقة بين المسؤولية الإجتماعية وتنافسيته دول العالم

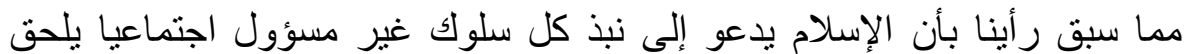

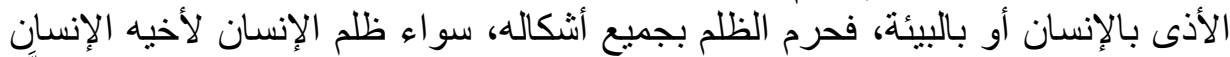

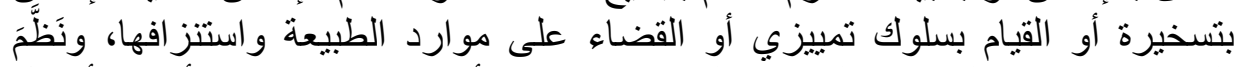

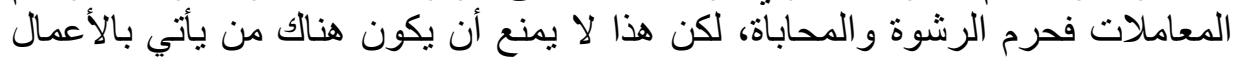

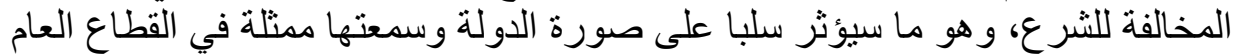
كما سيؤثر على تنافسية قطاع الأعمال ممثلا للقطاع الخاص.

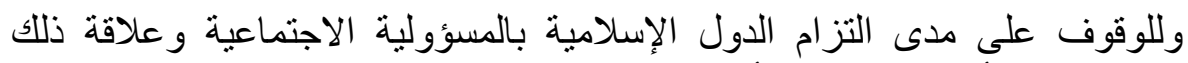

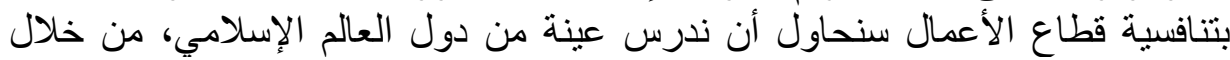

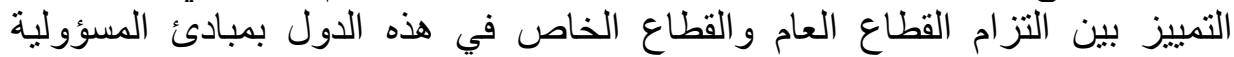
الاجتماعية و علاقة ذلك بتنافسية قطاع الأعمال.

\section{1- 1 - 1 - مجتمع الاراسة}

يشتمل العالم الإسلامي وفق (منظمة التعاون الإسلامي، 2014) على 57 دولة منها

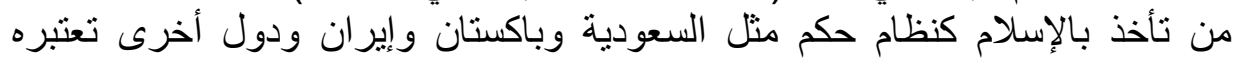
الديانة الرسمية ودول ترتفع فيها نسبة المسلمين. 


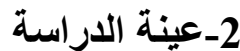

تغطي الدراسة 33 دولة أي بنسبة 58 \% وهي الدول التي يمثل فيها المسلمون

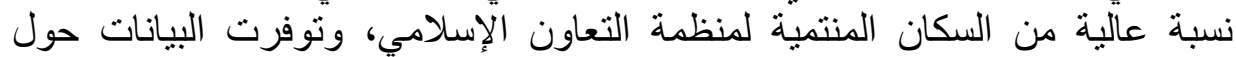
مؤشرات تنافسية قطاع الأعمال ومؤشرات حول المات المارسة العات المات المرنبطة بالمسؤولية الاجتماعية من طرف القطاع العام.

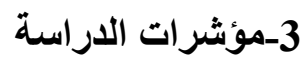

للحكم على مستويات تطبيق المسؤولية الاجتماعية والتنافسية سنجري دراسة

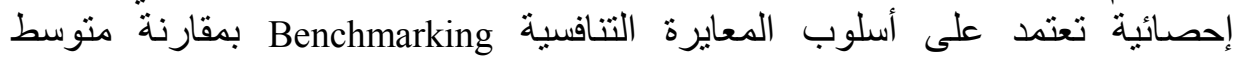
مؤشرات عينة دول العالم الإسلامي بالمتوسط السائد للمؤشر اتش على على المستوى الدولي.

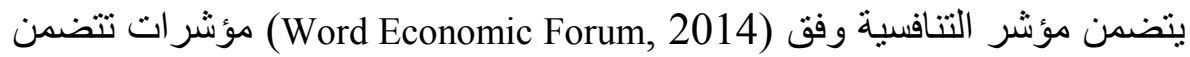

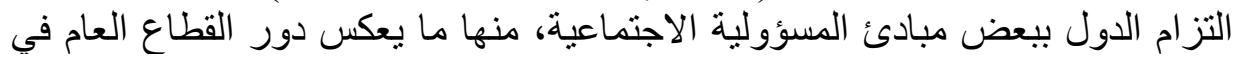

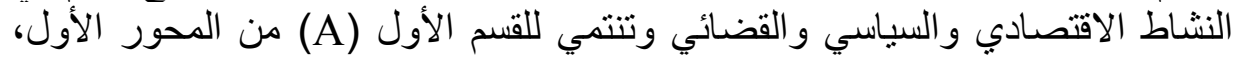

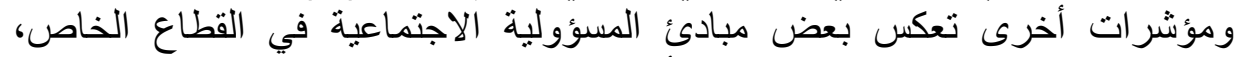
وتتنمي للقسم الثاني (B) من المحور الأول، كما يوضح الهن الجدول:

الجدول- 1- مؤشرات مبادئ المسؤولية الاجتماعية وفق المنتدى الاقتصادي العالمي

\begin{tabular}{|c|c|}
\hline القطاع الخاص & القطاع العام \\
\hline للشركات؛ & - - 1.03 تحويل الأمو ال العامة؛ \\
\hline و إعداد التقارير؛ 1.18 قوة معايير المراجعة & 1.04 ثقة الجمهور في السياسيين؛ \\
\hline - & و الرشاوى؛ $1.05 \quad$ المدفوعات $\quad$ غير $\quad$ النظامية \\
\hline - & - \\
\hline 1.21 قوة حماية المستثمر. & الحكو ميين؛ 1.07 المحاباة في قرارات المسؤولين \\
\hline l & 1.08 التبذير في الإنفاق الحكومي؛ \\
\hline l & 1.12 شفافية السياسات الحكومية. \\
\hline
\end{tabular}

المصدر: من إعداد الباحث

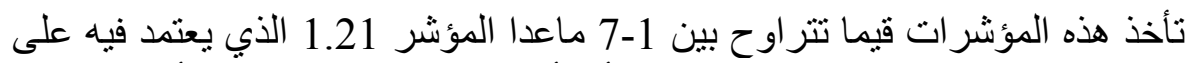

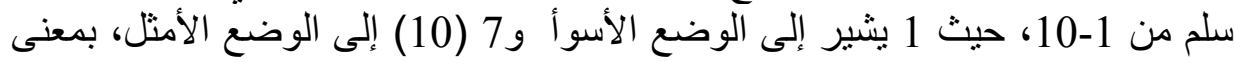

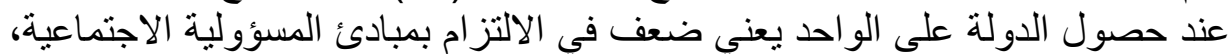




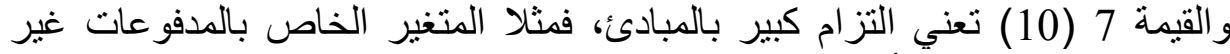

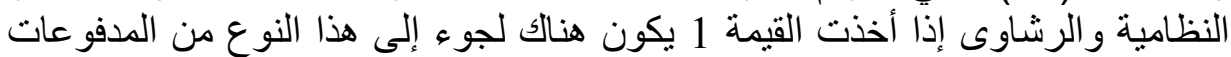

و العكس.

أما مؤشر تنافسية قطاع الأعمال، فسنعبر عنه بالمؤشر 11.04 و الذي يبين مدى الأى الأي

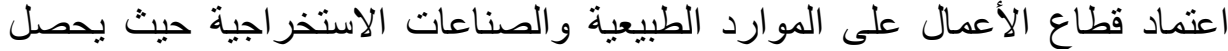
البلا على قيمة متدنية ولكن بازدياد استخدام تكنولوجيات متقدمة ومنتجات متميزة الألية

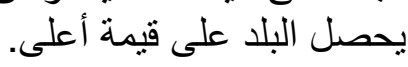

و البيانات الخاصة بالمؤشرات، استخلصناها من التقرير الصادرة عن المنتدى التهائ الاقتصادي العالمي في تقريره عن التنافسية لسنة 2014-2015 و هو التقرير الذي التي

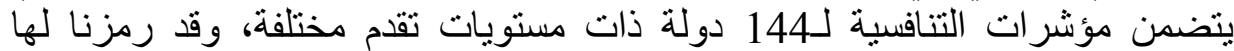
(المتغيرات) بالرمز VAR منبو عا برمز المؤشر في التقرير، فمثنا مؤشر التنافسية

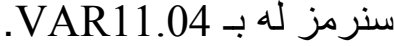

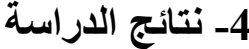

يمكن تلخيص نتائج الدراسة في الأشكال البيانية المدرجة في الملحق (1)، و التي التي

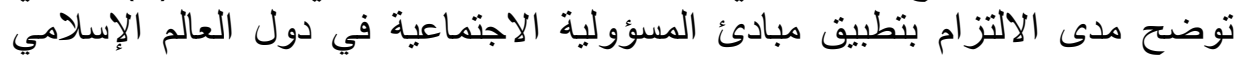

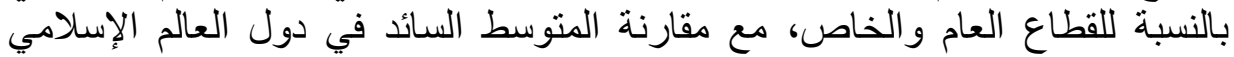
بالمتوسط السائد على المستوى الدولئ

\section{1-4 متوسط مؤشرات القطاع العام}

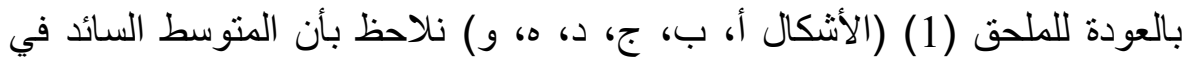

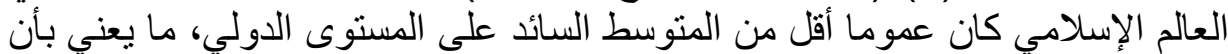

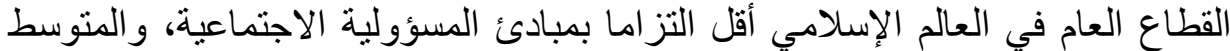

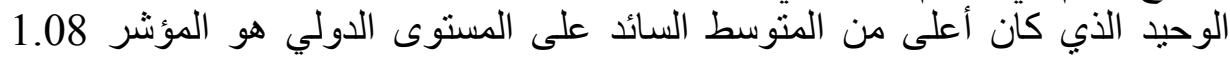

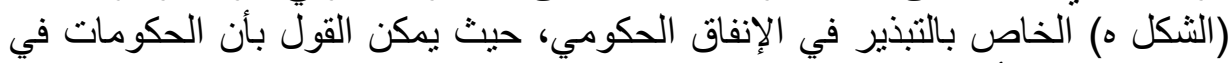

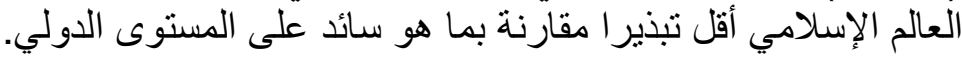

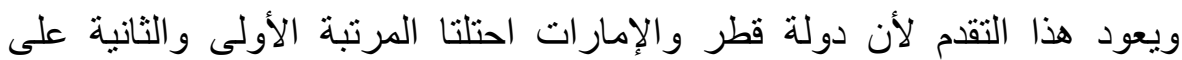
الترتيب وتلتهما سلطنة عمان في المرتبة السادسة وماليزيا في المرتبة الثامنة و والمملكة

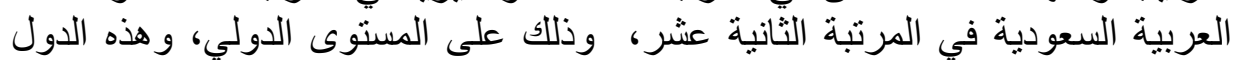

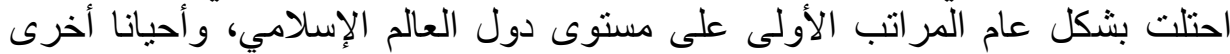

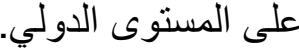

2-4- متوسط مؤشرات القطاع الخاص

تبين الأشكال (ز، ح، ط، ي، ك) بأن متوسط الالتز ام بمبادئ المسؤولية الاجتماعية

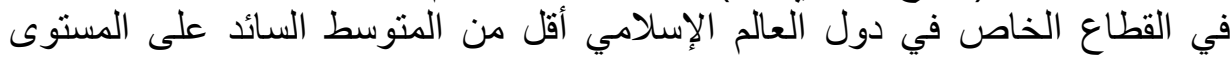


العالمي بالنسبة لجميع المؤشرات، وقد احتلت كل من قطر و الإمار ات وماليزيا وسلطنة عمان والمملكة العربية السعودية مراتب متقدمة على التى مستوى العالم الإسلامي وأحيانيا على المستوى الدولي.

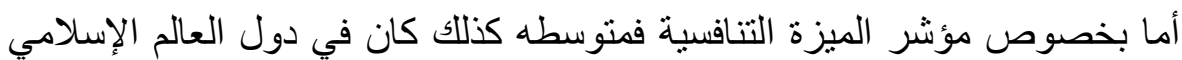

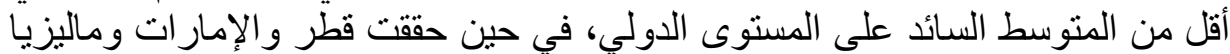

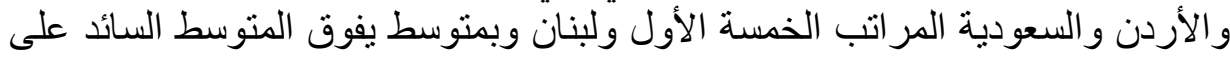
المستوى العالمي.

أما الثكل ل فيبين تراجع تنافسية قطاع الأعمال في دول العالم الإسلامي مقارنة

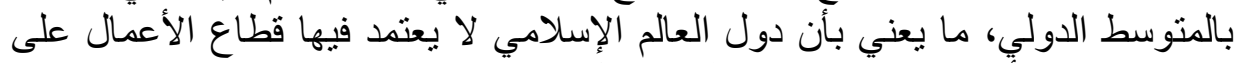

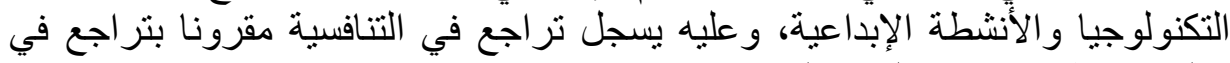
الالنز ام بتطبيق مبادئ المسؤولية الاجتماعية.

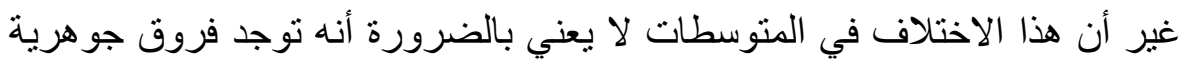

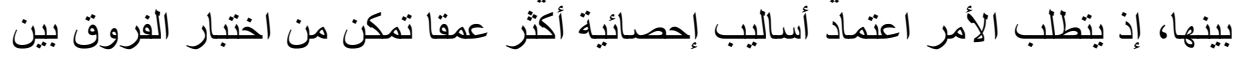

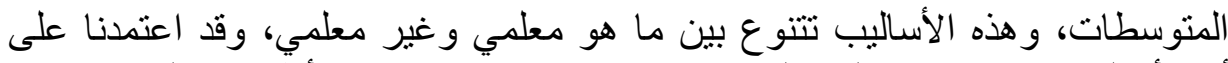

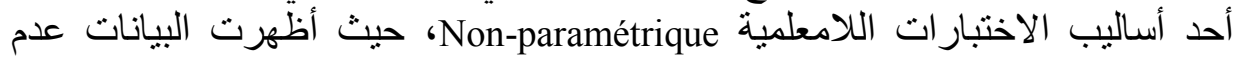
إمكانية تطبيق الطرق المعلمية ونخص بالذكر اختبار التباين أحادي الاتجاه لعدم توفر

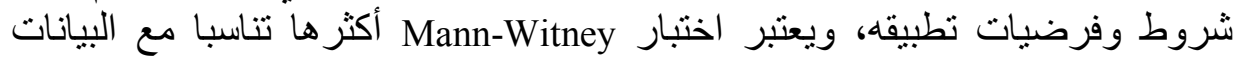
التي توفرت لدينا.

فكانت النتائج كما هي موضحة في الملحق (2)، الذي يظهر عدم وجود التود تمانتل في

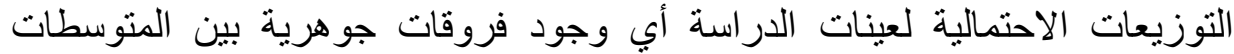

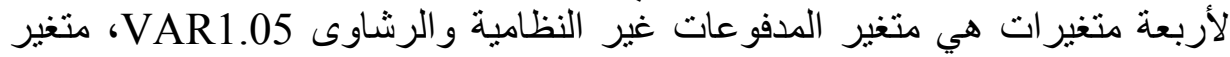

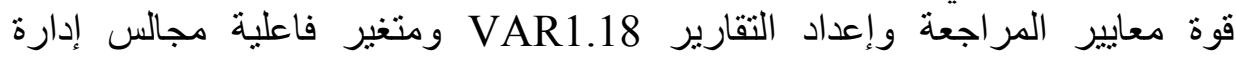

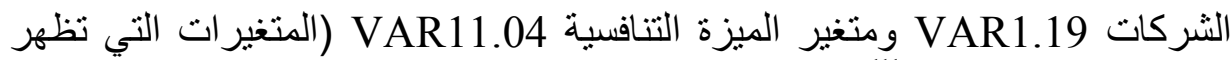
فيها نتائج الفرضيات مُظَلَّة)، وكانت نتائج بقية المتغير ات تظهر تماثنا في التوزيع.

\section{3-4-4 العلاقة بين التنافسية والمسؤولية الإجتماعية}

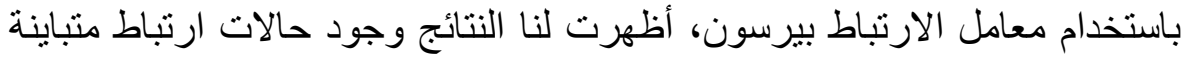

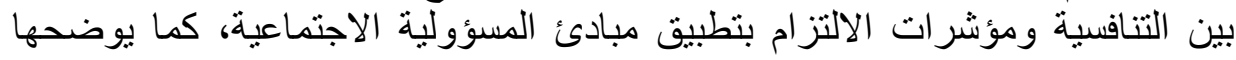

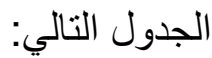

الجدول- 2- العلاقة بين مؤشرات المسؤولية الإجتماعية والتنافسية

\begin{tabular}{|l|l|l|l|l|l|l|l|l|l|l|l|l|}
\hline & & & & & & & & & & & & \\
& VAR & VAR & VAR & VAR & VAR & VAR & VAR & VAR & VAR & VAR & VAR & VAR \\
& 1.03 & 1.04 & 1.05 & 1.06 & 1.07 & 1.08 & 1.12 & 1.17 & 1.18 & 1.19 & 1.20 & 1.21 \\
\hline
\end{tabular}




\begin{tabular}{|c|c|c|c|c|c|c|c|c|c|c|c|c|c|}
\hline & $\mathrm{R}$ & ${ }_{*}, 821^{*}$ & , $772^{*}$ & ,799* & ${ }_{*}^{8} 804^{*}$ & ,828* &, $757^{*}$ & , $789^{*}$ & ${ }_{*}, 852^{*}$ & ${ }_{*}, 802^{*}$ & ${ }_{*}, 682^{*}$ & , $854^{*}$ & ,230 \\
\hline & Sig. & ,000 & ,000 & ,000 &, 000 & ,000 &, 000 & ,000 &, 000 & ,000 &, 000 &, 000 & , 197 \\
\hline $\begin{array}{l}\text { VAR } \\
11.04\end{array}$ & $\mathrm{R}^{2}$ & 0,674 & 0,596 & 0,638 & 0,646 & 0,686 & 0,573 & 0,623 & 0,726 & 0,643 & 0,465 & 0,729 & 0,053 \\
\hline
\end{tabular}

**. La corrélation est significative au niveau 0.01 (bilatéral).

*. La corrélation est significative au niveau 0.05 (bilatéral).

المصدر: إعداد الباحث بناء على برنامج SPSS.

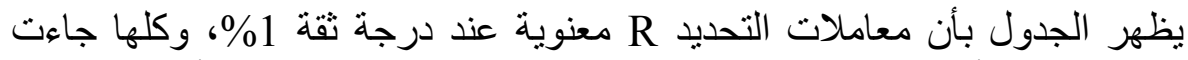

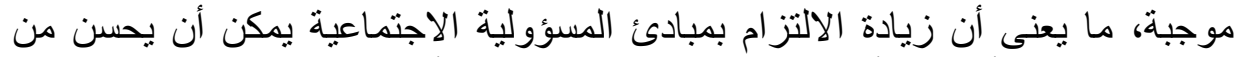

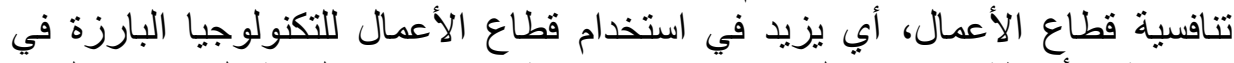

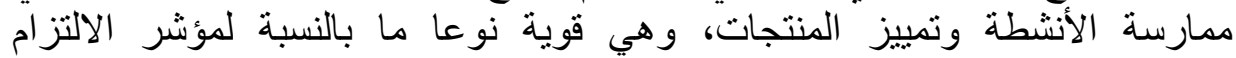

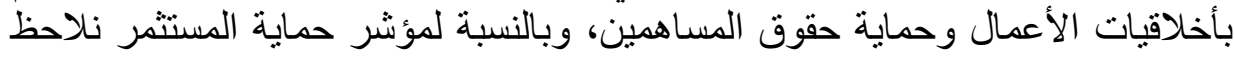

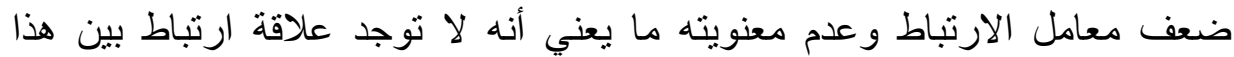
المتغير ومتغير الميزة التنافسية.

هذه النتائج على العموم، تؤكد على وجود ولئ علاقة بين المسؤولية الاجتماعية

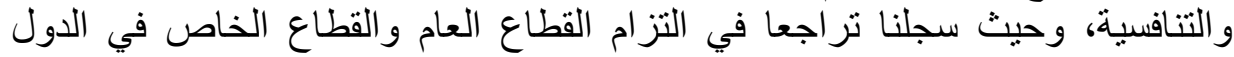

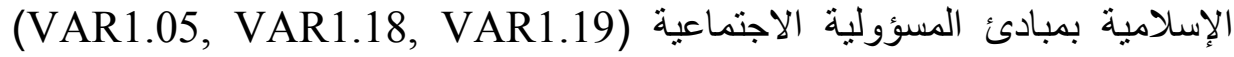

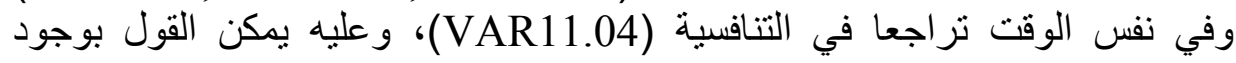
علاقة بين المسؤولية الاجتماعية والتنافسية.

هذه العلاقة عند محاولة ترجمتها في نموذج للانحدار المتعدد، وباستخدام طريقة

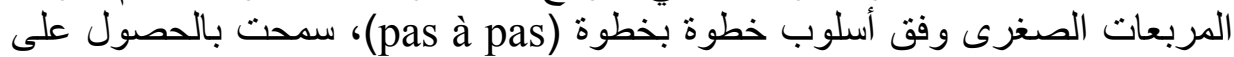

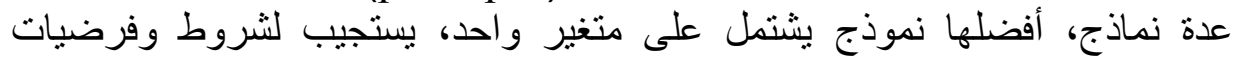

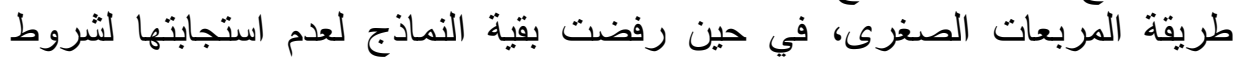
الطريقة المعتمدة، و هذا النموذج المقتر ح ملخص فيما يلي: 
ANOVAa الجدول- 3- تحليل التباين

\begin{tabular}{|c|c|c|c|c|c|}
\hline Modèle & $\begin{array}{l}\text { Somme des } \\
\text { carrés }\end{array}$ & ddl & $\begin{array}{l}\text { Moyenne des } \\
\text { carrés }\end{array}$ & D & Sig. \\
\hline Régression & 98,769 & 1 & 98,769 & 239,602 &, $000^{\mathrm{b}}$ \\
\hline Résidu & 58,535 & 142 & ,412 & & \\
\hline Total & 157,304 & 143 & & & \\
\hline
\end{tabular}

a. Variable dépendante : VAR11.04

b. Valeurs prédites : (constantes), VAR1.17

المصدر: إعداد الباحث بناء على برنامج SPSS.

ومعادلة الانحدار التي تعطي أفضل تقدير:

الجدول- 4- معادلة الاتحدار

\begin{tabular}{|c|c|c|c|c|c|}
\hline \multirow[t]{2}{*}{ Modèle } & $\begin{array}{l}\text { Coeffi } \\
\text { standa }\end{array}$ & & $\begin{array}{l}\text { Coefficients } \\
\text { standardisés }\end{array}$ & $\mathrm{t}$ & \multirow[t]{2}{*}{ Sig. } \\
\hline & $\mathrm{A}$ & \begin{tabular}{|l} 
Erreur \\
standard
\end{tabular} & Bêta & & \\
\hline $\begin{array}{ll}1 & \text { (Constante) } \\
1 & \text { VAR1.17 }\end{array}$ & $\begin{array}{l}-, 215 \\
.944\end{array}$ & $\begin{array}{l}260 \\
.061\end{array}$ & .792 & $\begin{array}{l}-, 827 \\
15,479\end{array}$ & $\begin{array}{l}410 \\
000\end{array}$ \\
\hline
\end{tabular}

a. Variable dépendante : VAR11.04

المصدر: إعداد الباحث بناء على برنامج SPSS.

فهذا النموذج يشتمل على متغير واحد تابع يعبر عن المسؤولية الاجتماعية وهو

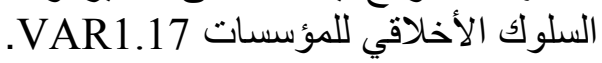

إن هذه النتائج تعكس وجها غير مشرف للإسلام لإى أصحاب الرؤية الضيقة الذي الذي الإني

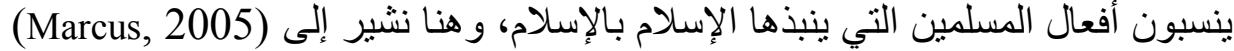

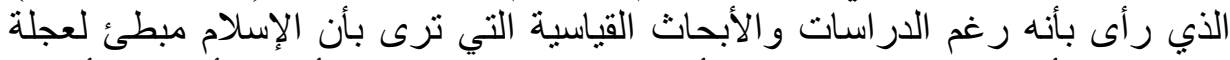

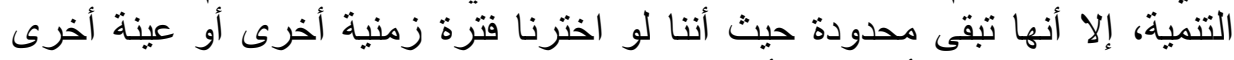

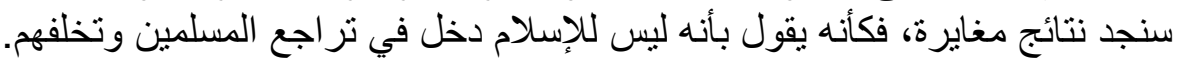


بينت الدراسة بأن المسؤولية الاجتماعية هي مفهوم يتطور مع تطور المنظمات

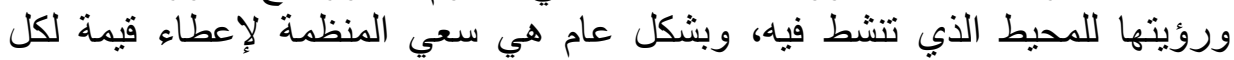

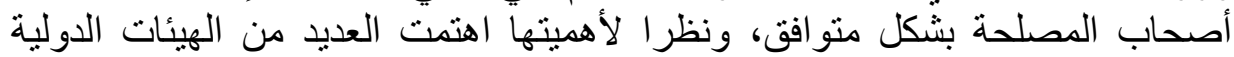
و الإقليمية بها و أعطت لها مبادئ غير ملزمة، مشيرة بأن الأن الالتز ام بها سيعطي للمنظمات

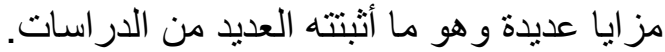

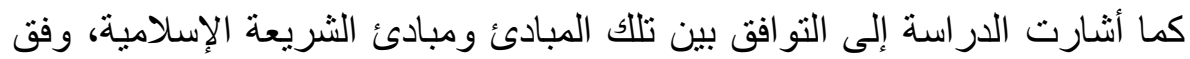

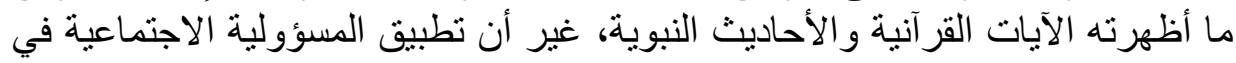

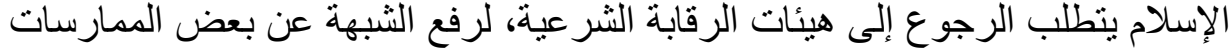

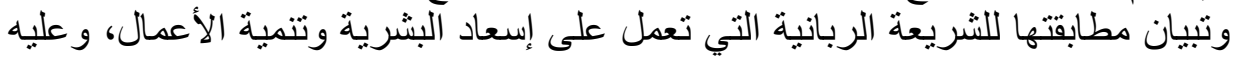

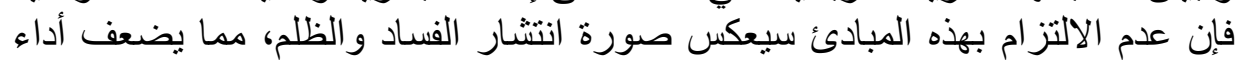
المنظمات وتنافسيتها ومن ثمة تنافسية الاقتصاد ككل.

وقد حاولت الدراسة التأكد من مدى التزام دول العالم الإسلامي بمبادئ المسؤولية

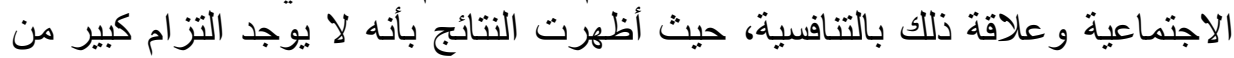

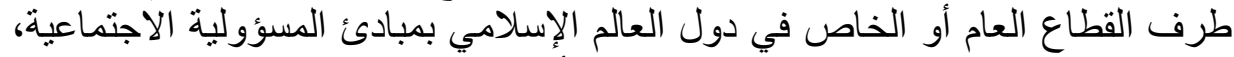

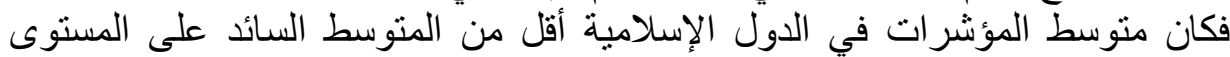

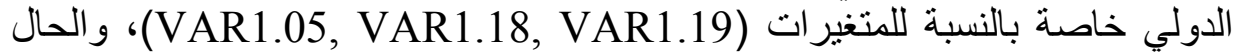
نفسه بالنسبة لمؤشر التنافسية.

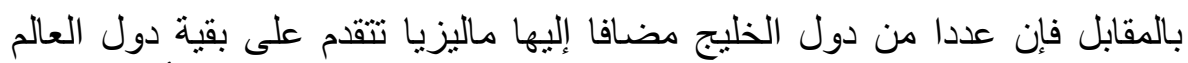

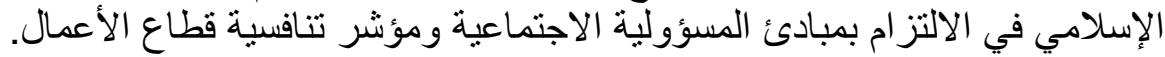
إن محدودية التزام منظمات القطاع العام والخاص في دول العالم الإسلامي بمبادئ

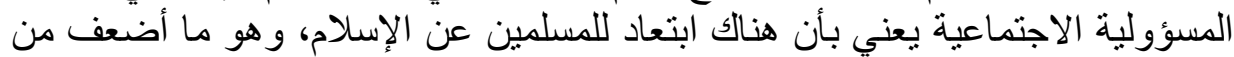

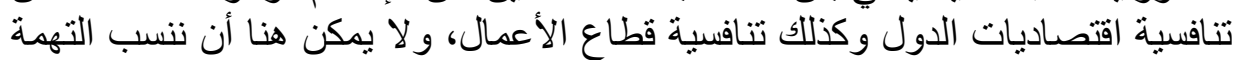
بالإسلام كما يحاول البعض فعل ذلك.

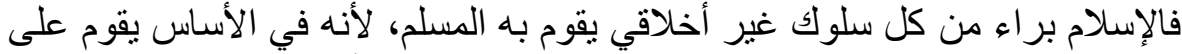

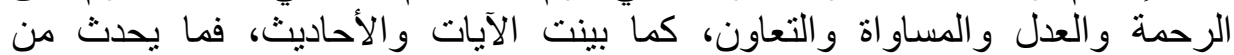

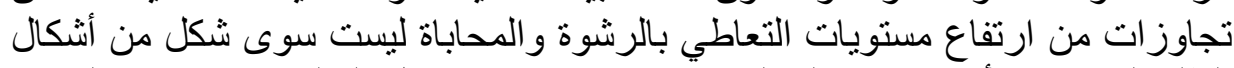

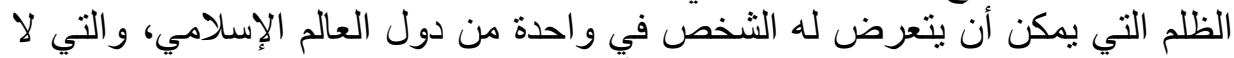

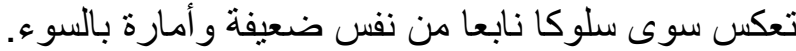

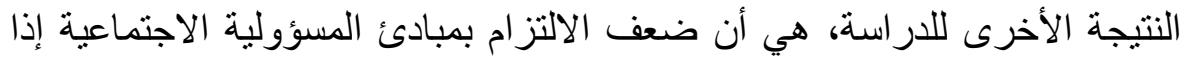

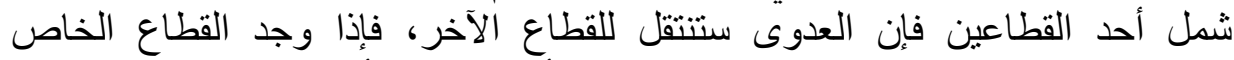
إجراءات بيروقر اطية وصعوبات في ممارسة الأعمال، سيلجأ إلى تجاوز ها لإن عن طريق 
دفع الرشوة، بالمقابل سيطلب القطاع العام الرشوة من القطاع الخاص إذإ كان هذا

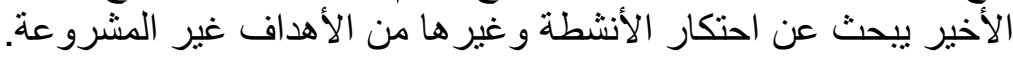

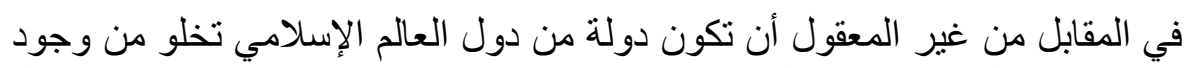

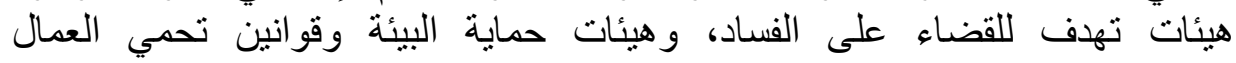

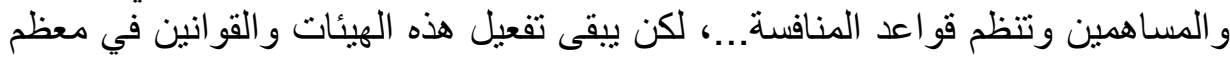

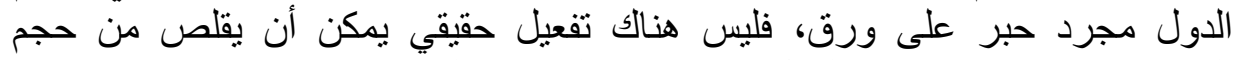
التجاوزات التي تعاني منها الدول الإسلامية و العربية على وجلية على التحديد. و عليه نورد بعض التوصيات، نجملها فيما يلي: تعائ

- توعية القائمين على القطاع العام والخاص بالمضار التي تتنج عن ممارسات

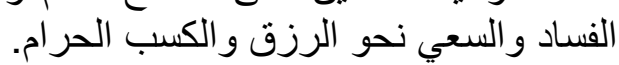
- - إلغاء القيود و الإجر اءات البيروات البيروقر اطية التي تعرقل القيام بالأعمال.

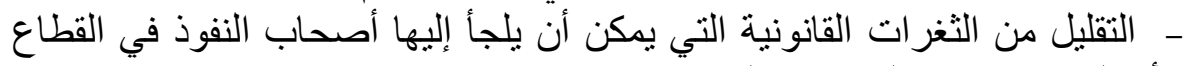

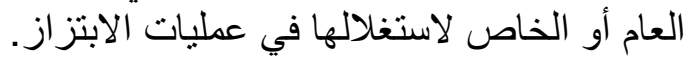

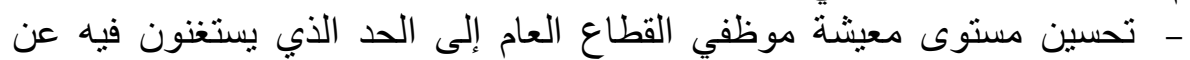

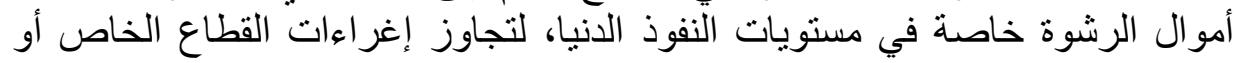

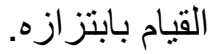

- - تفعيل هيئات الرقابة و المحاسبة و الإجر اءات التي تعمل بها.

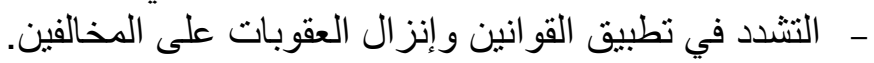

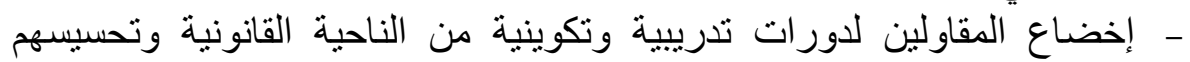

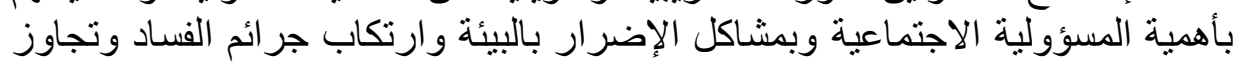
قو انين التشغيل.

\section{الهوامش}

http:/library.islamweb.net اعتمدنا في وضع الأحاديث على الموقعين الإكترونين

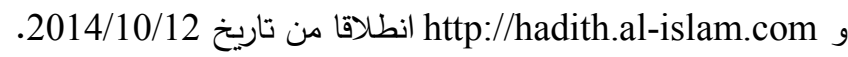
2- هي النسخة التي اعتمدنا عليها، حيث ان اول ظهور للكتاب كان سنة 1985.

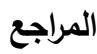

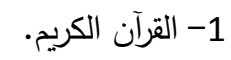

2- ابن خلدون عبد الرحمن، (طبعة 2004)، مقدمة ابن خلدون، (تحقيق: عبد الله محمد

$$
\text { الدرويش)، دمشق: دار يعرب. }
$$




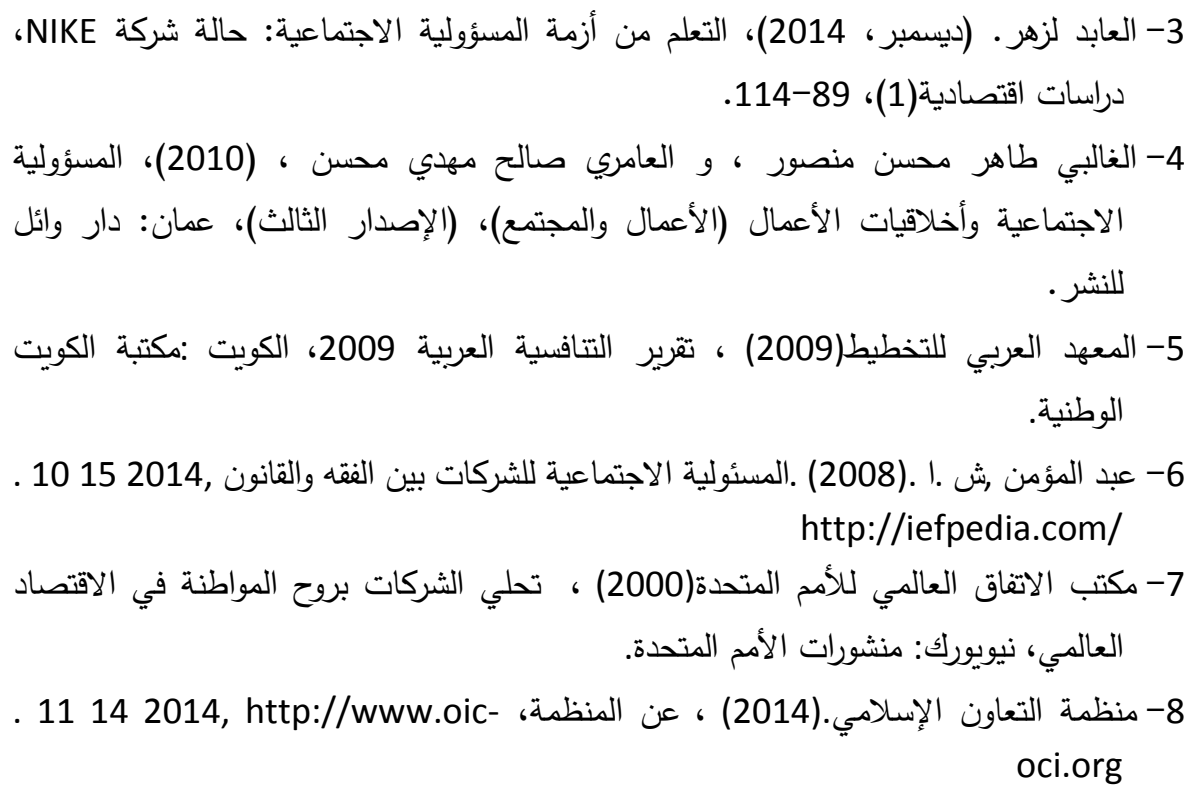

1. Armstrong, J. S. (1977, September). Social irresponsibility in management, Volume 5, Issue 3, September. Journal of Business Research, 5(3), pp. 185-213.

2. BCG. (1980). Les mécanismes fondamentaux de la compétitivité. Paris: édition Hommes et techniques.

3. Blackburn, K., Gonzalo, F., \& Puccio, F. (2009, December). Why is corruption less harmful in some countries than in others? Journal of Economic Behavior \& Organization, 72(3), pp. 797-810.

4. Bron Taylor. (2004, November). A green future for religion? Futures, 36(9), pp. 991-1008.

5. Burke, L., \& Logsdon, J. M. (1996, August). How corporate social responsibility pays off, Volume 29, Issue 4, Pages. Long Range Planning,, 29(4), pp. 495-502.

6. Carroll, A.B. (1999). Corporate social responsibility: Evolution of a definitional construct. Business \& Society, 38(3), pp. 268-295.

7. Carroll, A. B. (1979, October). A Three-Dimensional Conceptual Model of Corporate Social Performance. Academy of Management Review, 4(4), 497-505.

8. Carroll, A. B. (1991, July-August ). A The pyramid of corporate social responsibility: Toward the moral management of organizational stakeholders. Business Horizons, 34(4), 39-48.

9. Commission Européenne. (2011). Responsabilité sociale des entreprises: une nouvelle stratégie de l'UE pour la période 2011-2014. Bruxelles.

10. Duane, W. (2013, October). Corporate social responsibility and irresponsibility: A positive theory approach. Journal of Business Research, 66(10), pp. 19371944.

11. Farook, S., Hassan, M., \& Lanis, R. (2011). Determinants of corporate social responsibility disclosure: The case of Islamic bank. Journal of Islamic Accounting and Business Research, 2(2), pp. 114-141. 
12. Friedman, M. (1970, September 13). The Social Responsibility of Business is to Increase its Profits. The New York Times Magazine, p. 1.

13. ISO. (2010). ISO 26000:2010(fr) [Lignes directrices relatives à la responsabilité sociétale]. Retrieved 01 21, 2014, from https://www.iso.org

14. Maden, C., Arıkan, E., Telci, E., \& Kantur, D. (2012, October 12). Linking Corporate Social Responsibility to Corporate Reputation: A Study on Understanding Behavioral Consequences. Social and Behavioral Sciences, pp. 655-664.

15. Mallin, C., Farag, H., \& Ow-Yong, K. (2014, July). Corporate social responsibility and financial performance in Islamic banks. Journal of Economic Behavior \& Organization, 103, pp. S21-S38.

16. Marcus, N. (2005, August). Religion and economic performance. World Development, pp. 1215-1232.

17. McFetridge, D. (1995, April). Competitiveness: Concepts and Measures. Retrieved 04 19, 2007, from https://www.ic.gc.ca/

18. OCDE. (2001). Corporate Social Responsibility : Partners for Progress. Paris: Éditions OCDE.

19. Porter, M. (1990, Marsh-April). The competitive advantage of nation. HBR, pp. 71-91.

20. Porter, M. (1993). L'avantage concurrnetiel des nations. Paris: Inter-édition.

21. Porter, M. (1999). L'avantage concurrentiel: comment devencer ses concurrents et maintenir son avance. Paris: Dunod.

22. Putrevu, S., McGuire, J., Siegel, D. S., \& Smith, D. M. (2012, November). Corporate social responsibility, irresponsibility, and corruption: Introduction to the special section. Journal of Business Research, 65(11), pp. 1618-1621.

23. Saed Adnan, M., Abdul Rahim, O., \& Selvan, P. (2012, December). Corporate Social Responsibility and Company Performance in the Malaysian Context. Social and Behavioral Sciences, 65(3), pp. 897-905.

24. Sweetin, V. H., Knowles, L. L., Summey, J. H., \& McQueen, ,. K. (2013, October). Willingness-to-punish the corporate brand for corporate social irresponsibility. Journal of Business Research, 66(10), 1822-1830.

25. Tafti, S. F., Hosseini, S. F., \& Akbari Emami, S. (2012, October). Assessment the Corporate Social Responsibility According to Islamic Values (Case Study: Sarmayeh Bank). Social and Behavioral Sciences, 58, pp. 1139-1148.

26. Word economic forum. (2014). The Global Competitiveness Report 2014-2015. Geneva: Full Data Edition.

27. Yazilmiwati, Y., \& Ilhaamie, A. G. (2012, October). Entrepreneur's Social Responsibilities From Islamic Perspective: A Study of Muslim Entrepreneurs In Malaysia. Social and Behavioral Sciences, 58, pp. 1131-1138.

28. HYPERLINK "http://library.islamweb.net" http://library.islamweb.net

29. http://hadith.al-islam.com 


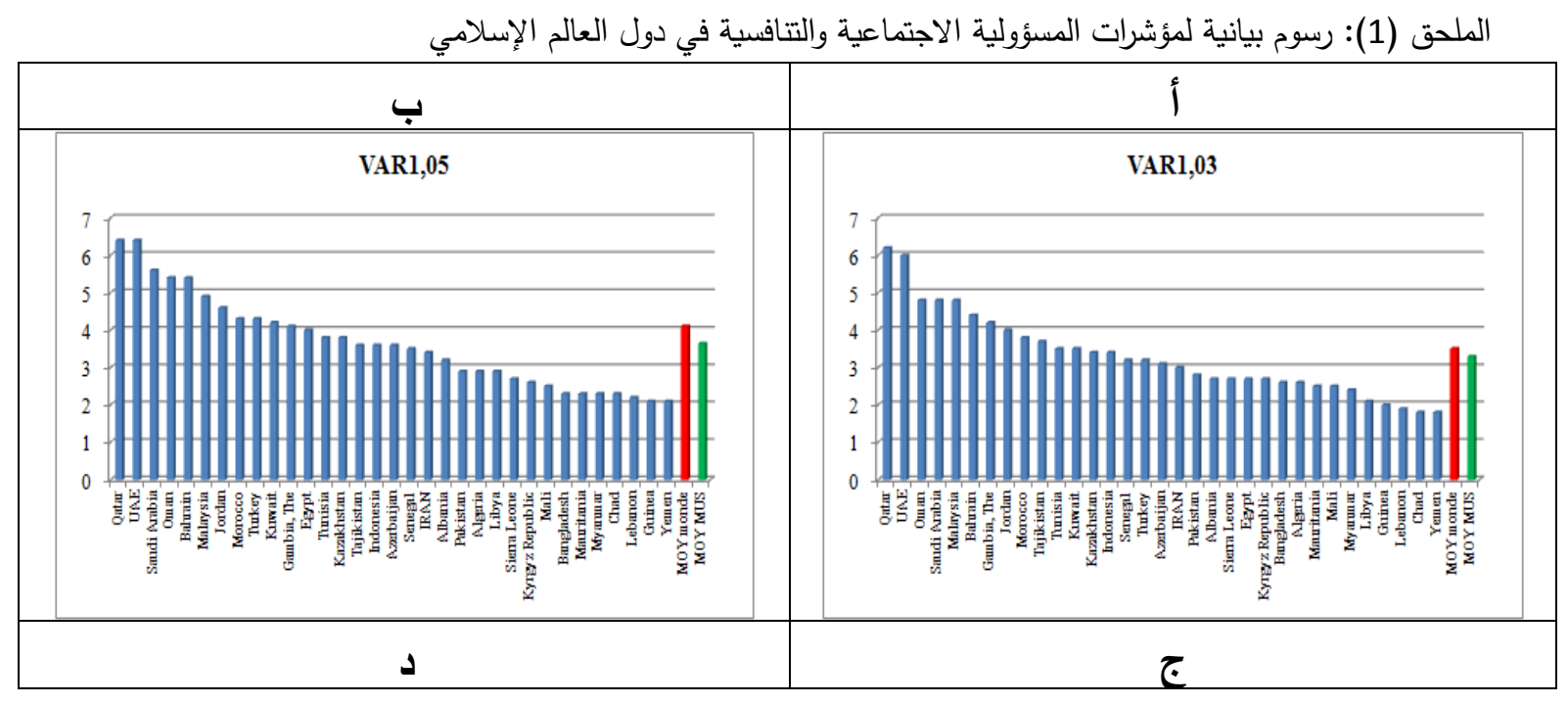




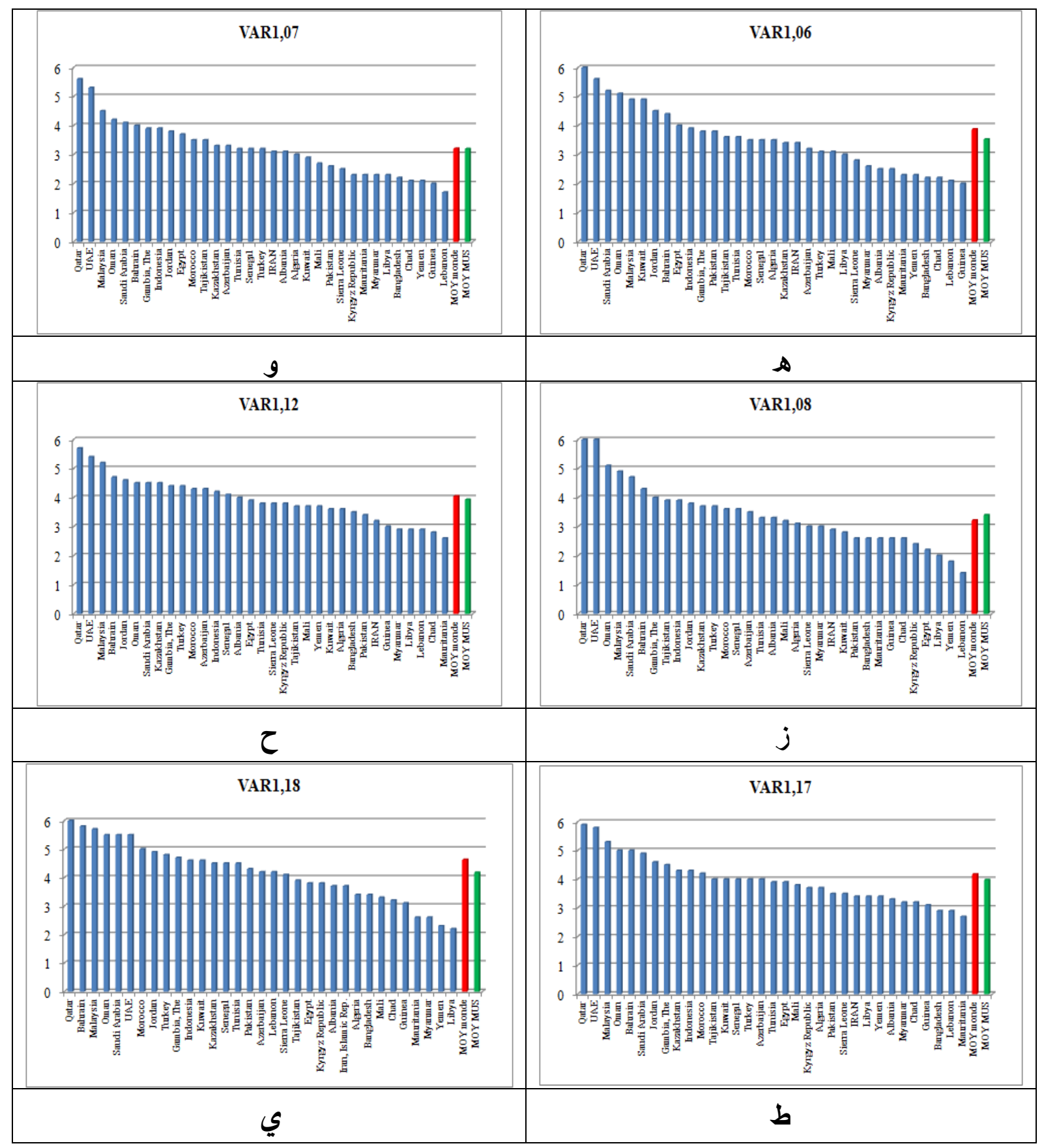




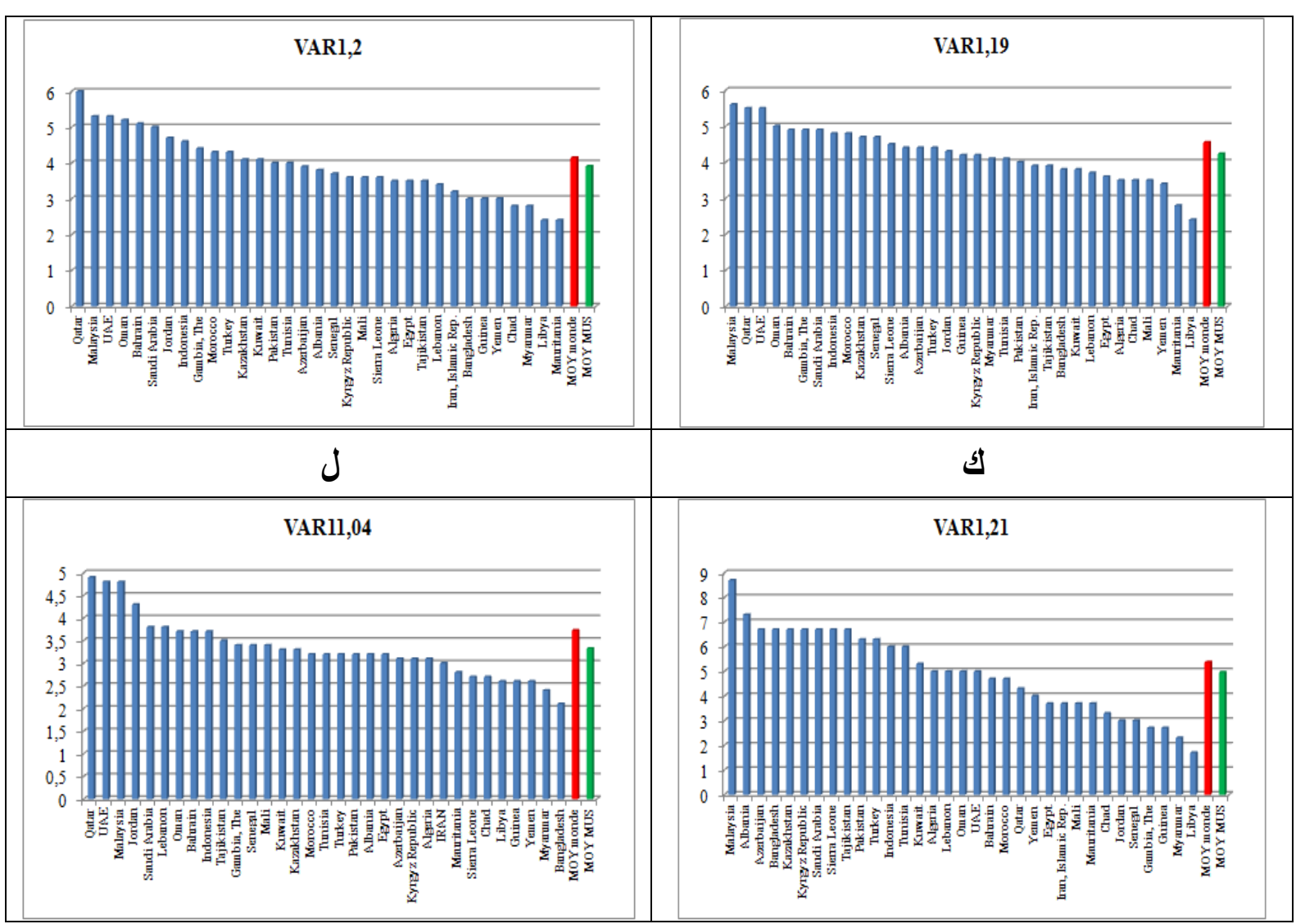

المصدر : إعداد الباحث بناء على بيانات المنتى الاقتصادي العالمي. 